\title{
Current Algorithm for Treatment of Advanced NSCLC Patients: How to Include Active Immunotherapy?"
}

\author{
Gisela Gonzalez $^{1 \#}$, Arlhee Diaz-Miqueli ${ }^{1}$, Tania Crombet ${ }^{1}$, Luis E. Raez ${ }^{2}$, Agustin Lage ${ }^{1}$ \\ ${ }^{1}$ Center of Molecular Immunology, Havana, Cuba; ${ }^{2}$ Memorial Cancer Institute, Memorial Health Care System, Florida International \\ University, Miami, USA. \\ Email: "giselagm2007@yahoo.com
}

Received July $19^{\text {th }}, 2013$; revised August $18^{\text {th }}, 2013$; accepted August $26^{\text {th }}, 2013$

Copyright (C) 2013 Gisela Gonzalez et al. This is an open access article distributed under the Creative Commons Attribution License, which permits unrestricted use, distribution, and reproduction in any medium, provided the original work is properly cited.

\begin{abstract}
Despite the availability of different treatments for advanced NSCLC, all of them have a palliative intention and a cure for the disease is unlikely. Thus, advanced lung cancer remains as an unmet medical need. Chemotherapy has been used as the therapy of choice for advanced NSCLC patients, but it is mainly limited by the patient's performance status. More recently, targeted therapies have introduced more specific treatment options that show efficacy in specific niche of patients, but precisely due to their target specificity, they usually provoke early resistance. In addition to these limitations, most of the best drugs currently used for treatment of advanced NSCLC show small increases in patient survival with severe associated toxicity. Novel drugs with low toxicity that could be given chronically to control the advanced disease can make a difference. They could allow the management of advanced cancer as a chronic disease that, even when not cured, it can be controlled for long periods of time offering patients a good quality of life. Active-specific immunotherapy is an area of oncology that is rapidly expanding with encouraging results. Cancer vaccines against many potential targets have shown to increase patient survival in clinical trials at all stages NSCLC, when included as first-line, maintenance, or second-line therapy. Safety of cancer vaccines supposes a new hope for cancer therapy, and this unique characteristic makes it possible to be used in sub-sets of patients that cannot receive other approved treatments because of their high toxicity. In this paper, authors propose how active immunotherapy could be included in the current algorithm for treatment of advanced NSCLC patients.
\end{abstract}

Keywords: Lung Cancer Therapy; Active Immunotherapy; Cancer Vaccines

\section{Introduction}

Lung cancer has been the most common cancer in the world for several decades, and by 2008, there were an estimated 1.61 million new cases, representing $12.7 \%$ of all new cancers. Lung cancer is the leading cause of cancer mortality in the US and worldwide, accounting for 1.38 million deaths $(18.2 \%$ of the total) [1]. Lung cancer figures show a close similarity between incidence and mortality, demonstrating that almost all patients diagnosed with lung cancer died from the disease. Approximately $85 \%$ of newly diagnosed lung cancers are categorized as non-small cell lung cancers (NSCLC) [2]. NSCLC includes squamous cell carcinoma, adenocarcinoma, and large cell carcinoma. Unlike other common types of solid tumors, such as breast cancer and colon cancer, there are

*Dr Luis E. Raez has received research support from Glaxo-Smith Kline and Merck Serono.

${ }^{*}$ Corresponding author. no approved screening modalities for early detection of lung cancer in the general population [3]. As a result, many of these patients have locally advanced or metastatic disease by the time they become symptomatic and present for care. Patients with stage IIIb or IV NSCLC are deemed to have unresectable tumors and, while they may benefit from palliative chemotherapy, radiation or both, a cure is unlikely. Even if the tumor can be completely resected, the 5 -year mortality is $40 \%$ in stage I disease, $66 \%$ in stage II disease, and $75 \%$ in stage IIIa loco-regional disease. Micrometastases are commonly left behind after surgical resection, resulting in eventual relapse. As such, a diagnosis of NSCLC carries a poor prognosis under all circumstances [4].

Lung cancer is usually diagnosed at advanced stages, when the disease is not curable, and available therapies are mainly palliatives. Several drugs are available for treatment of advanced NSCLC, some of them are limited to a 
specific niche of patients, showing only a marginal improvement in patient survival (real clinical impact) with high or moderate associated toxicity. For those reasons, advanced lung cancer remains as an unmet medical need. Advanced NSCLC patients are not always amenable to receive the existing onco-specific therapies. Chemotherapies are very toxic and tolerated only by patients with an acceptable performance status (PS). Other biologic drugs have demonstrated effect only in small group of patients with specific genetic characteristics; but given its high specificity, these drugs usually develop resistance.

Additionally, when patients receive all possible oncospecific treatments and have disease progression, they are considered "terminal patients" that will only receive best supportive care to enhance as much as possible their quality of life. But at this stage, even with tumor progression, patients can live with a quality of life that will depend on the management of their disease. Another group of patients, who are unfit for available treatments are amenable to receive non-toxic treatments that might help increase overall survival with a good quality of life, such as immunetherapies. This is the case of cancer vaccines that can be given chronically due to its low toxicity, even in advanced stages of disease $[5,6]$. That means a major change in advanced cancer treatment: the possibility of a chronic treatment that converts advanced cancer into a controlled chronic disease, offering patients a good quality of life.

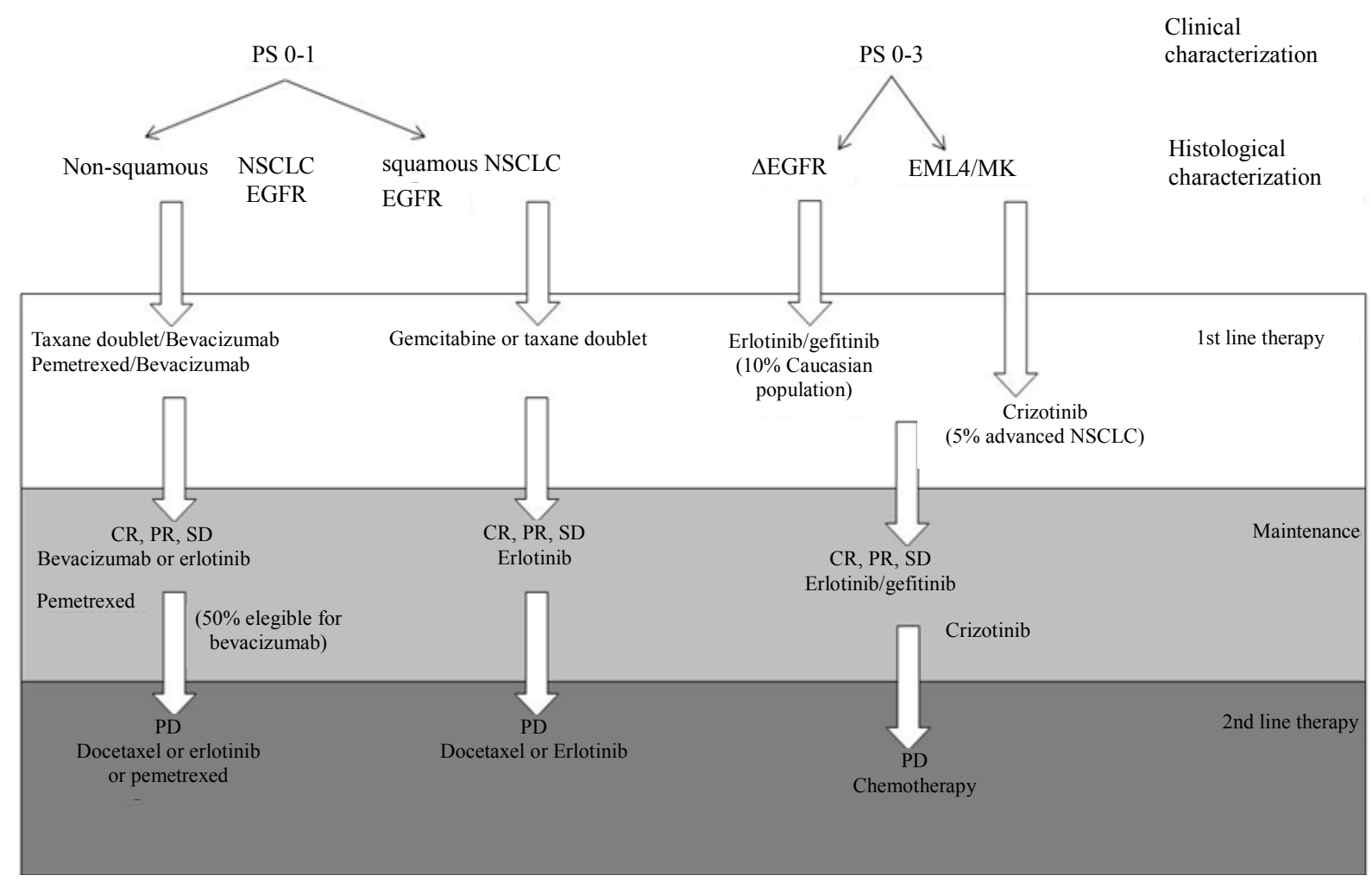

Figure 1. Current algorithm of treatment of advanced NSCLC patients.
In this scenario, biotechnology has become an important source of new products for cancer treatment. According to the 2011 Pharma Report, from 900 biotechnological products under development, 352 are devoted to cancer treatment: 170 are monoclonal antibodies and 90 are cancer vaccines. That means $40 \%$ of worldwide biotechnology now is devoted to cancer immunotherapy. Biotechnology gives technological tools for obtaining products that can be designed and produced to target specifically tumor cells. Their specificity gives them a precious advantage translated in a better toxicity profile when compared with current onco-specific therapies (i.e. chemotherapy) that provoke systemic toxicity due to their lack of specificity for tumor cells. In this paper we review the state of the art in NSCLC therapy; the algorithm of existing treatments for advanced (stages IIIb and IV) NSCLC patients; and how non-toxic therapies (i.e. cancer vaccines) can be inserted in such algorithm for patient's benefit.

\section{Which Is the Current Algorithm for Treatment of Advanced NSCLC?}

The current algorithm for therapy of advanced NSCLC, takes into account the patients characteristics; basically: PS, tumor histology and the presence of "driver mutations" (Figure 1). Once diagnosed, a patient with advanced NSCLC must be characterized according these

$$
\text { (1) }
$$


to decide the most appropriated treatment to be assigned. According to this algorithm, available therapies can be used in first-line, maintenance and second-line therapy in patients, depending of their clinical, histological and molecular tumor characteristics. However, currently approved therapies have a limited potential to increase patient survival and a high or moderate toxicity (Table 1).

Chemotherapy, as first-line treatment for advanced
NSCLC (PS 0-1) offers a median OS of approximately 10 months, with associated hematologic toxicity, nephrotoxicity, nausea and vomiting [7]. The addition of bevacizumab to the first-line therapy in non-squamous NSCLC (PS 0-1), increased in 2 months the median OS of chemotherapy, but added new severe adverse events such as hypertension, proteinuria, bleeding, febrile neutropenia, thrombocytopenia, hyponatremia, rash, and headache [8].

The use of tyrosine kinase inhibitors (TKI) gefitinib

Table 1. How the currently available therapies for advanced NSCLC patients have been approved.

\begin{tabular}{|c|c|c|c|c|c|}
\hline Drug/combination & Patients & Treatment line & Safety & Efficacy & Ref \\
\hline Platinum-based & Advanced NSCLC & $\begin{array}{l}\text { First Line } \\
\text { PS } 0-1\end{array}$ & $\begin{array}{l}\text { Hematologic toxicity, } \\
\text { nephrotoxicity, and nausea } \\
\text { and vomiting }\end{array}$ & $\begin{array}{l}\text { RR } 34 \% \\
\text { OS } 10 \text { months }\end{array}$ & [7] \\
\hline $\begin{array}{l}\text { Carboplatin+ paclitaxel } \\
+ \text { bevacizumab }\end{array}$ & $\begin{array}{l}\text { Non squamous } \\
\text { NSCLC }\end{array}$ & $\begin{array}{l}\text { First Line } \\
\text { PS } 0-1\end{array}$ & $\begin{array}{l}\text { Hypertension, proteinuria, } \\
\text { bleeding, neutropenia, febrile } \\
\text { neutropenia, thrombocytopenia, } \\
\text { hyponatremia, rash, and } \\
\text { headache }\end{array}$ & $\begin{array}{l}\text { OS (CP - bev vs. CP): } \\
12.3 \text { vs. } 10.3 \text { months } \\
\text { PFS (CP - bev vs. CP): } \\
6.2 \text { vs. } 4.5 \text { months }\end{array}$ & {$[8]$} \\
\hline Gefitinib & EGFR mutant & $\begin{array}{l}\text { First line } \\
\text { PS } 0-3\end{array}$ & $\begin{array}{l}\text { Rash and diarrhea with } \\
\text { gefitinib, and appetite loss, } \\
\text { sensory neuropathy, and } \\
\text { myelotoxicities }\end{array}$ & $\begin{array}{l}\text { PFS (gefitinib vs. CTP): } \\
10.8 \text { vs } 5.4 \text { months } \\
\text { OS (gefitinib vs. CTP): } \\
27.7 \text { vs. } 26.6 \text { months }\end{array}$ & [10] \\
\hline Erlotinib & EGFR mutant & $\begin{array}{l}\text { First line } \\
\text { PS } 0-3\end{array}$ & $\begin{array}{l}\text { Rash and increased } \\
\text { aminotransferase } \\
\text { concentrations }\end{array}$ & $\begin{array}{l}\text { ORR (erlotinib vs. CTP): } \\
58 \% \text { vs. } 15 \% \\
\text { PFS: } 13.1 \text { vs. } 4.6 \text { months }\end{array}$ & [9] \\
\hline Crizotininb & $\begin{array}{l}\text { ALK-EML4 m } \\
\text { Fusion protein }\end{array}$ & $\begin{array}{l}\text { First line } \\
\text { PS } 0-3\end{array}$ & $\begin{array}{l}\text { Visual effects, nausea, } \\
\text { diarrhea, constipation, } \\
\text { vomiting, and peripheral } \\
\text { oedema }\end{array}$ & $\begin{array}{l}\text { OR: } 60.8 \% \\
\text { Median PFS was } \\
9.7 \text { months }\end{array}$ & [11] \\
\hline Pemetrexed & $\begin{array}{l}\text { Non squamous } \\
\text { NSCLC }\end{array}$ & $\begin{array}{l}\text { Continuation } \\
\text { maintenance } \\
\text { PS 0-1 }\end{array}$ & $\begin{array}{l}\text { Anaemia, neutropenia, } \\
\text { and fatigue }\end{array}$ & $\begin{array}{l}\text { PFS (pemetrexed vs. } \\
\text { placebo): } 4.1 \text { vs } 2.8 \\
\text { months }\end{array}$ & [12] \\
\hline Pemetrexed & $\begin{array}{l}\text { Non squamous } \\
\text { NSCLC }\end{array}$ & $\begin{array}{l}\text { Switch maintenance } \\
\text { PS } 0-1\end{array}$ & Neutropenia and fatigue & $\begin{array}{l}\text { PFS (pemetrexed vs. } \\
\text { placebo): } 4.3 \text { vs } 2.6 \\
\text { months } \\
\text { OS (pemetrexed vs. } \\
\text { placebo): } 13.4 \text { vs } 10.6 \\
\text { months }\end{array}$ & [13] \\
\hline Docetaxel & NSCLC & $\begin{array}{l}\text { Switch maintenance } \\
\text { PS } 0-1\end{array}$ & $\begin{array}{l}\text { Neutropenia, thrombocytopenia, } \\
\text { anemia, fatigue, dyspnea }\end{array}$ & $\begin{array}{l}\text { PFS (immediate vs. } \\
\text { delayed): } 5.7 \text { vs } 2.7 \\
\text { months }\end{array}$ & [14] \\
\hline Erlotinib & NSCLC & $\begin{array}{l}\text { Switch maintenance } \\
\text { PS } 0-3\end{array}$ & Rash & $\begin{array}{l}\text { PFS (pemetrexed vs. } \\
\text { observation): } \\
2.9 \text { vs } 1.9 \text { months }\end{array}$ & [15] \\
\hline Docetaxel & NSCLC & $\begin{array}{l}\text { Second line } \\
\text { PS } 0-1\end{array}$ & $\begin{array}{l}\text { Neutropenia and febrile } \\
\text { neutropenia }\end{array}$ & $\begin{array}{l}\text { OS (docetaxel vs. BSC): } \\
7.5 \text { vs } 4.6 \text { months }\end{array}$ & [16] \\
\hline Pemetrexed & $\begin{array}{l}\text { Non squamous } \\
\text { NSCLC }\end{array}$ & $\begin{array}{l}\text { Second line } \\
\text { PS } 0-1\end{array}$ & $\begin{array}{l}\text { Neutropenia and febrile } \\
\text { neutropenia }\end{array}$ & $\begin{array}{l}\text { OS (pemetrexed vs. } \\
\text { docetaxel): } 8.3 \text { vs } 7.5 \\
\text { months }\end{array}$ & [17] \\
\hline Erlotinib & NSCLC & $\begin{array}{l}\text { Second line } \\
\text { PS } 0-3\end{array}$ & $\begin{array}{l}\text { Diarrhea, rash, anorexia, } \\
\text { nausea }\end{array}$ & $\begin{array}{l}\text { OS (erlotinib vs. } \\
\text { docetaxel): } \\
6.7 \text { vs } 4.7 \text { months }\end{array}$ & [18] \\
\hline
\end{tabular}

Abbreviations: BSC, best supportive care; bev, bevacizumab; CP, carboplatin; CPT, cisplatin; NSCLC, non-small cell lung cancer; OS, overall survival; ORR, overall response rates; PFS, progression-free survival; PS, performance status; RR, response rates. 
and erlotinib as first-line in patients with mutated forms of the epidermal growth factor receptor (EGFR) NSCLC (PS 0-3) (10\% of advanced NSCLC patients among Caucasian population), increased in 5.4 months the PFS without modifying the OS as compared to chemotherapy alone for this small number of patients, with adverse events typical of TKIs, including cutaneous rash and diarrhea $[9,10]$. More recently, crizotinib was approved for using in NSCLC patients, PS 0-3, that present the ALKEML4 fusion protein (only 5\% of advanced NSCLC patients) as first-line therapy because its ability to increase PFS—-but not OS—in advanced NSCLC patients [11]. Adverse events associated to the administration of crizotinib include visual effects, nausea, diarrhea, constipation, vomiting, and peripheral edema.

In maintenance therapy, pemetrexed was approved as continuation maintenance in PS 0-1 non-squamous NSCLC patients [12]. In this setting, pemetrexed added 1.3 months in PFS, despite this increase was not translated into a better OS. It has also been used as switch maintenance therapy in this group of patients showing an increase of 2.8 months in OS [13]. Pemetrexed-related adverse events include anemia, neutropenia, and fatigue. Docetaxel it is also used as switch maintenance therapy resulting in a 3-month increase PFS, despite this is not translated into a better OS [14]. Most frequent docetaxelassociated adverse events are neutropenia, thrombocytopenia, anemia, fatigue and dyspnea. Erlotinib as switch maintenance therapy has shown to increase progression free survival, but not OS, of treated patients [15].

In the scenario of second-line therapy, docetaxel was approved for treating patients with PS 0-1, increasing OS in 2.9 months as compared with best supportive care, but adding the previously described adverse events associated to the use of this drug [16,17]. Erlotinib was also approved in this setting, but in patients with PS 0-3, with a two-month increased OS compared with docetaxel, and associated-adverse events (diarrhea, cutaneous rash, anorexia and nausea) [18].

Looking at these figures, the approved drugs for advanced NSCLC therapies have still a limited impact in patient OS (maximum of 3 months), and its use is frequently associated with the occurrence of severe averse events that affect patient's quality of life. Therefore, new approaches are needed to improve current outcomes [19].

\section{What Is Coming as Second-Generation Agents for Treatment of Advanced NSCLC Patients?}

As has been previously described, erlotinib and gefitinib are currently used in the first-line treatment of patients with advanced NSCLC and EGFR-activating mutations, as well as second- and third-line settings in unselected patients, regardless of EGFR mutations status [20]. However, patients that initially respond to this treatment, usually develops acquired resistance after a median of 12 16 months [21]. Once progression occurs, further treatment options are very limited due to the performance status of patients who are unable to tolerate toxicities associated to cytotoxic chemotherapy. Thus, new therapy options are urgently needed after the progression to firstgeneration anti-EGFR agents. Molecularly targeted therapies under investigation in NSCLC include ErbB family blockers, multityrosine kinase inhibitors, c-Met inhibitors and antiangiogenic agents. Table 2 summarizes the phase II and phase III clinical trials of investigational new drugs for the treatment of advanced NSCLC patients.

Most of the second generation of TKI acts through an irreversible, covalent binding to ATP-binding site in the kinase domains of the EGFR [22]. This covalent binding leads to longer suppression of tyrosine kinase activity, as it is suppressed until the synthesis of new receptors. Among the second generation of TKIs afatinib has shown thus far the most extensive evaluation with promising results, being recently approved in July 2013 as firstline therapy for patients with EGFR mutations [23-26]. However, the general consensus for using afatinib as a second- or third-line treatment in patients with EGFR activating mutations is that the drug does not differs from current approved first-generation TKIs gefitinib and erlotinib in terms of OS or PFS when used for unselected patients and does not have FDA approval for that.

The amplification of the Met gene is another mechanism of resistance to currently available targeted treatments for NSCLC [27]. Tivatinib is a non-ATP-competitive inhibitor of the Met signaling pathway, which has been extensively tested as a second-line therapy, in combination with TKI erlotinib in patients with or without EGFR-activating mutations. However, a phase II trial initially conducted with tivantinib failed to increase OS and PFS compared with erlotinib plus placebo [28]. Moreover, a subsequent phase III trial was recently stopped early after an interim analysis that showed the study would not meet its primary endpoint of OS [29].

In 2006, the US Food and Drug Administration approved bevacizumab for the first-line treatment of patients with advanced non-squamous NSCLC in combination with cytotoxic drugs carboplatin and paclitaxel [30]. However, the develop of tumor resistance frequently occurs, permitting only the half of the patients being eligible for bevacizumab therapy [31]. For such reason, a considerable number of new antiangiogenic agents are currently being evaluated for the treatment of patients with NSCLC in combination with cytotoxic drugs, including sorafenib and sunitinib. Nevertheless, sorafenib did not meet its primary endpoint in two separate large 
Table 2. Phase II and phase III clinical trials of investigational new drugs for the treatment of advanced NSCLC patients.

\begin{tabular}{|c|c|c|c|c|c|c|c|}
\hline Trial design & Patients & $\begin{array}{c}\text { Drug/ } \\
\text { combination }\end{array}$ & $\begin{array}{l}\text { Treatment } \\
\text { line }\end{array}$ & $\begin{array}{c}\text { Most common } \\
\text { grade } \geq 3 \text { AEs }(\%)\end{array}$ & $\begin{array}{c}\text { Efficacy } \\
\text { (primary endpoint) }\end{array}$ & $\begin{array}{c}\text { Trial } \\
\text { success }\end{array}$ & Ref \\
\hline \multicolumn{8}{|l|}{ Afatinib } \\
\hline $\begin{array}{l}\text { LUX-Lung2; } \\
\text { phase II; } \\
(\mathrm{N}=129) \\
\text { Ongoing/not } \\
\text { recruiting }\end{array}$ & $\Delta \mathrm{EGFR}$ & Afa $v s$ Placebo & $\begin{array}{l}\text { First- and } \\
\text { second-line } \\
\text { PS: } 0-2\end{array}$ & $\begin{array}{l}\text { Diarrhea } 22 ; \\
\text { rash } 28 \text { at } 50 \mathrm{mg} \\
\text { Diarrhea } 7 ; \\
\text { rash } 7 \text { at } 40 \mathrm{mg}\end{array}$ & (RR: 61\%) & $\begin{array}{l}\text { Met primary } \\
\text { endpoint }\end{array}$ & {$[24]$} \\
\hline $\begin{array}{l}\text { LUX-Lung1; } \\
\text { phase IIb/III; } \\
(\mathrm{N}=585) \\
\text { Completed }\end{array}$ & $\begin{array}{l}\text { Advanced/ } \\
\text { metastatic NSCLC }\end{array}$ & Afa $v s$ Placebo & $\begin{array}{l}\text { Second- or } \\
\text { third-line } \\
\text { PS: } 0-2\end{array}$ & Diarrhea 17; rash 14 & $\begin{array}{l}\text { (OS: } 10.8 v s \\
12.0 \text { months) } \\
\text { PFS: } 3.3 v s \\
1.1 \text { months }\end{array}$ & $\begin{array}{l}\text { Did not met } \\
\text { primary } \\
\text { endpoint }\end{array}$ & {$[26]$} \\
\hline $\begin{array}{l}\text { LUX-Lung3; } \\
\text { phase III; } \\
(\mathrm{N}=345) \\
\text { Ongoing/not } \\
\text { recruiting }\end{array}$ & $\Delta \mathrm{EGFR}$ & Afa $v s$ Cis/Pem & $\begin{array}{l}\text { First-line } \\
\text { PS: } 0-2\end{array}$ & Diarrhea; Rash & $\begin{array}{l}\text { (PFS: } 11.1 \text { vs } \\
6.9 \text { months) }\end{array}$ & $\begin{array}{l}\text { Met primary } \\
\text { endpoint }\end{array}$ & {$[25]$} \\
\hline $\begin{array}{l}\text { LUX-Lung6; } \\
\text { phase III; } \\
(\mathrm{N}=364) \\
\text { Ongoing/not } \\
\text { recruiting }\end{array}$ & $\triangle \mathrm{EGFR}$ & Afa $v s \mathrm{Gem} / \mathrm{Cis}$ & $\begin{array}{l}\text { First-line } \\
\text { PS: } 0-2\end{array}$ & NR & (PFS) NR & NR & None \\
\hline \multicolumn{8}{|l|}{ Tivantinib } \\
\hline $\begin{array}{l}\text { Phase II } \\
(\mathrm{N}=167) \\
\text { Completed }\end{array}$ & Advanced NSCLC & $\begin{array}{l}\text { Erlotinib/Tiv } v s \\
\text { Erlotinib/Placebo }\end{array}$ & Second-line & & $\begin{array}{l}\text { (PFS: } \mathbf{3 . 8} \text { vs } \mathbf{2 . 3} \text { months) } \\
\text { OS: } 8.5 \text { vs } 6.9 \text { months }\end{array}$ & $\begin{array}{l}\text { Did not met } \\
\text { primary } \\
\text { endpoint }\end{array}$ & {$[28]$} \\
\hline $\begin{array}{l}\text { MARQUEE } \\
\text { Phase III } \\
(\mathrm{N}=988) \\
\text { Ongoing/not } \\
\text { recruiting }\end{array}$ & $\begin{array}{l}\Delta \mathrm{EGFR} / \\
\Delta \mathrm{K}-\mathrm{ras} / \\
\text { Met amplif }\end{array}$ & $\begin{array}{l}\text { Erlotinib/Tiv } \\
\text { vs Erlotinib/ } \\
\text { Placebo }\end{array}$ & Second-line & NR & (PFS) NR & & {$[29]$} \\
\hline \multicolumn{8}{|l|}{ Sorafenib } \\
\hline $\begin{array}{l}\text { ESCAPE; } \\
\text { phase III; } \\
(\mathrm{N}=926) \\
\text { Halted }\end{array}$ & $\begin{array}{l}\text { Advanced } \\
\text { NSCLC }\end{array}$ & $\begin{array}{l}\mathrm{Car} / \mathrm{Pac} / \mathrm{Sor} v s \\
\mathrm{Car} / \mathrm{Pac} / \mathrm{Plac}\end{array}$ & First-line & $\begin{array}{l}\text { Rash (9), hand-foot } \\
\text { disease (8) }\end{array}$ & $\begin{array}{l}\text { (OS: } 10.7 \text { vs } \\
\text { 10.6 months) PFS: } \\
4.6 \text { vs } 5.4 \text { months }\end{array}$ & $\begin{array}{l}\text { Did not met } \\
\text { primary } \\
\text { endpoint }\end{array}$ & {$[32]$} \\
\hline $\begin{array}{l}\text { NExUS; } \\
\text { Phase III; } \\
(\mathrm{N}=904) ; \\
\text { Completed }\end{array}$ & $\begin{array}{l}\text { Advanced } \\
\text { NSCLC }\end{array}$ & $\begin{array}{l}\text { Gem/Cis/Pla vs } \\
\text { Gem/Cis/Sor }\end{array}$ & First-line & $\begin{array}{l}\text { Thrombocytopenia }(9.9) \\
\text { Hand-foot skin } \\
\text { reaction }(8.6) \\
\text { Fatigue }(7.3)\end{array}$ & $\begin{array}{l}\text { (OS: } \mathbf{3 7 6} \text { vs } \\
\text { 379 days) } \\
\text { PFS: } 183 v s \\
168 \text { days }\end{array}$ & $\begin{array}{l}\text { Did not met } \\
\text { primary } \\
\text { endpoint }\end{array}$ & {$[33]$} \\
\hline \multicolumn{8}{|l|}{ Sunitinib } \\
\hline $\begin{array}{l}\text { SABRE-L; } \\
\text { phase II; } \\
(\mathrm{N}=56) \\
\text { Terminated }\end{array}$ & $\begin{array}{l}\text { Advanced } \\
\text { NSCLC }\end{array}$ & $\mathrm{Car} / \mathrm{Pac} / \mathrm{Bev} / \mathrm{Sun}$ & First-line & $\begin{array}{l}\text { Neutropenia (65.5) } \\
\text { Thrombocytopenia (37.9) } \\
\text { Leukopenia (27.6) } \\
\text { Febrile neutropenia (13.8) } \\
\text { Hypertension (10.3) }\end{array}$ & $\begin{array}{l}\text { (Best tumor response): } \\
\text { PR (8\% vs 26\%) } \\
\text { PFS: } 3.8 \text { vs } 4.5 \text { months } \\
\text { OS: } 6.6 \text { months vs NR }\end{array}$ & $\begin{array}{l}\text { Did not met } \\
\text { primary } \\
\text { endpoint }\end{array}$ & {$[44]$} \\
\hline $\begin{array}{l}\text { CALGB30704; } \\
\text { phase II; } \\
(\mathrm{N}=225) ; \\
\text { Ongoing/not } \\
\text { recruiting }\end{array}$ & $\begin{array}{l}\text { Advanced } \\
\text { NSCLC }\end{array}$ & $\begin{array}{l}\text { A: Sun } \\
\text { B:Pem } \\
\text { C:Sun }+ \text { Pem }\end{array}$ & Second-line & NR & (PFS) NR & NR & None \\
\hline $\begin{array}{l}\text { phase II; } \\
(\mathrm{N}=16) \\
\text { Unknown }\end{array}$ & $\begin{array}{l}\text { Advanced } \\
\text { NSCLC }\end{array}$ & Sun/Doc/Cis & Salvage & NR & (RR) NR & NR & None \\
\hline $\begin{array}{l}\text { phase III; } \\
(\mathrm{N}=244) \\
\text { Recruiting }\end{array}$ & $\begin{array}{l}\text { Advanced } \\
\text { NSCLC }\end{array}$ & $\begin{array}{l}\text { Chemo }+ \text { Sun } \\
\text { maintenance } v s \\
\text { Chemo }+ \\
\text { maitenance }\end{array}$ & Maintenance & NR & (PFS) NR & NR & None \\
\hline
\end{tabular}


Continued

\begin{tabular}{|c|c|c|c|c|c|c|c|}
\hline \multicolumn{8}{|l|}{ Aflibercept } \\
\hline $\begin{array}{l}\text { VITAL; } \\
\text { phase III; } \\
(\mathrm{N}=913) ; \\
\text { Active }\end{array}$ & $\begin{array}{l}\text { Advanced } \\
\text { NSCLC }\end{array}$ & $\begin{array}{l}\text { Afli + Doc vs } \\
\text { Placebo+Doc }\end{array}$ & Second-line & NR & (OS) NR & $\begin{array}{l}\text { Did not met } \\
\text { primary } \\
\text { endpoint }\end{array}$ & [35] \\
\hline \multicolumn{8}{|l|}{ Vandetanib } \\
\hline $\begin{array}{l}\text { ZEAL; } \\
\text { phase III; } \\
(\mathrm{N}=510) ; \\
\text { Completed }\end{array}$ & $\begin{array}{l}\text { Advanced } \\
\text { NSCLC }\end{array}$ & $\begin{array}{l}\text { Van }+ \text { Pem } v s \\
\text { Placebo + Pem }\end{array}$ & Second-line & $\begin{array}{l}\text { Rash (6) } \\
\text { Diarrhea (4) }\end{array}$ & $\begin{array}{l}\text { (PFS 17.6 vs } \\
\text { 11.9 weeks) } \\
\text { OS } 10.5 \text { vs } \\
9.2 \text { weeks }\end{array}$ & $\begin{array}{l}\text { Met primary } \\
\text { endpoint }\end{array}$ & [36] \\
\hline $\begin{array}{l}\text { ZEST; } \\
\text { phase III; } \\
(\mathrm{N}=1240) ; \\
\text { Completed }\end{array}$ & $\begin{array}{l}\text { Advanced } \\
\text { NSCLC }\end{array}$ & $\begin{array}{l}\text { Van } v s \\
\text { Erlotinib }\end{array}$ & Second-line & $\begin{array}{l}\text { Rash (3) } \\
\text { Diarrhea (5) } \\
\text { Fatigue (4) } \\
\text { Dyspnea (4) }\end{array}$ & $\begin{array}{l}\text { (PFS 2.6 vs } \\
\mathbf{2 . 0} \text { months) } \\
\text { OS } 6.9 \text { vs } \\
7.8 \text { months }\end{array}$ & $\begin{array}{l}\text { Did not met } \\
\text { primary } \\
\text { endpoint }\end{array}$ & [43] \\
\hline $\begin{array}{l}\text { ZODIAC; } \\
\text { phase III; } \\
(\mathrm{N}=1391) ; \\
\text { Completed }\end{array}$ & $\begin{array}{l}\text { Advanced } \\
\text { NSCLC }\end{array}$ & $\begin{array}{l}\text { Van + Doc } v s \\
\text { Placebo + Doc }\end{array}$ & Second-line & $\begin{array}{l}\text { Rash (9) } \\
\text { Neutropenia (29) } \\
\text { Leukopenia (14) } \\
\text { Febrile } \\
\text { neutropenia (9) }\end{array}$ & $\begin{array}{l}\text { (PFS 4.0 } \\
\text { vs } 3.2 \text { months) } \\
\text { OS } 10.6 \text { vs } \\
10.0 \text { months }\end{array}$ & $\begin{array}{l}\text { Did not met } \\
\text { primary } \\
\text { endpoint }\end{array}$ & [42] \\
\hline $\begin{array}{l}\text { ZEPHYR; } \\
\text { phase III; } \\
\text { (N=924); } \\
\text { Completed }\end{array}$ & $\begin{array}{l}\text { Advanced } \\
\text { NSCLC }\end{array}$ & $\begin{array}{l}\text { Van } v s \\
\text { Placebo }\end{array}$ & $\begin{array}{l}\text { Second- or } \\
\text { third-line }\end{array}$ & NR & $\begin{array}{l}\text { (OS } 8.5 \text { vs } \\
7.8 \text { months) } \\
\text { PFS: NR }\end{array}$ & $\begin{array}{l}\text { Did not met } \\
\text { primary } \\
\text { endpoint }\end{array}$ & [40] \\
\hline
\end{tabular}

\section{Cediranib}

\begin{tabular}{|c|c|c|c|c|c|c|c|}
\hline $\begin{array}{l}\text { BR24; } \\
\text { phase II/III; } \\
(\mathrm{N}=296) ; \\
\text { Completed }\end{array}$ & $\begin{array}{l}\text { Advanced } \\
\text { NSCLC }\end{array}$ & $\begin{array}{l}\mathrm{Ced} / \mathrm{Car} / \mathrm{Pac} \\
\text { vs } \mathrm{Placebo} / \mathrm{Car} / \mathrm{Pac}\end{array}$ & First-line & $\begin{array}{l}\text { Hypertension (19) } \\
\text { Diarrhea (15) } \\
\text { Fatigue (29) } \\
\text { Dyspnea (10) }\end{array}$ & $\begin{array}{l}\text { (PFS) NR } \\
\text { OS: } 10.5 \\
\text { vs. } 10.1 \text { months }\end{array}$ & NR & [37] \\
\hline $\begin{array}{l}\text { BR29; } \\
\text { phase III; } \\
(\mathrm{N}=306) \\
\text { Closed }\end{array}$ & $\begin{array}{l}\text { Advanced } \\
\text { NSCLC }\end{array}$ & $\begin{array}{l}\mathrm{Ced} / \mathrm{Car} / \mathrm{Pac} \\
\text { vs } \mathrm{Placebo} / \mathrm{Car} / \mathrm{Pac}\end{array}$ & First-line & NR & (OS) NR & NR & None \\
\hline \multicolumn{8}{|l|}{ Nintedanib } \\
\hline $\begin{array}{l}\text { LUME-Lung1 } \\
\text { phase III; } \\
(\mathrm{N}=1300) ; \\
\text { Ongoing/not } \\
\text { recruiting }\end{array}$ & $\begin{array}{l}\text { Advanced } \\
\text { NSCLC }\end{array}$ & $\begin{array}{l}\text { Nin/Doc } v s \\
\text { Placebo/Doc }\end{array}$ & Second-line & NR & (PFS) NR & NR & None \\
\hline $\begin{array}{l}\text { LUME-Lung2 } \\
\text { phase III; } \\
(\mathrm{N}=1302) ; \\
\text { Ongoing/not recruiting }\end{array}$ & $\begin{array}{l}\text { Advanced } \\
\text { NSCLC }\end{array}$ & $\begin{array}{l}\text { Nin/Pem vs } \\
\text { Placebo/Pem }\end{array}$ & Second-line & NR & (PFS) NR & NR & None \\
\hline
\end{tabular}

Motesanib

\begin{tabular}{|c|c|c|c|c|c|c|c|}
\hline $\begin{array}{l}\text { phase II; } \\
(\mathrm{N}=186) ; \\
\text { Terminated }\end{array}$ & $\begin{array}{l}\text { Advanced } \\
\text { NSCLC }\end{array}$ & $\begin{array}{l}\text { A: } \\
\text { Mot } 125 \mathrm{mg} \text { once/ } \\
\text { daily/Pac/Car } \\
\mathrm{B}: \\
\text { Mot } 75 \mathrm{mg} \text { twice/ } \\
\text { daily/Placebo/Pac/ } \\
\text { Car } \\
\text { C: Car/Pac/Ava }\end{array}$ & First-line & $\begin{array}{l}\text { Diarrhea (19 and 11) } \\
\text { Fatigue (17) } \\
\text { Dehydration } \\
\text { (17 and } 11) \\
\text { Anorexia (12) }\end{array}$ & $\begin{array}{l}\text { (RR) } \\
\text { A: } \mathbf{3 0 \%} \text {; B: } \mathbf{2 3 \%} \\
\text { C: } \mathbf{3 7 \%} \\
\text { PFS } 7.7 \text { vs } 5.8 \\
\text { vs } 8.3 \text { months } \\
\text { OS: } 14.0 \text { vs } 12.8 \\
\text { vs } 14.0 \text { months }\end{array}$ & $\begin{array}{l}\text { Did not met } \\
\text { primary } \\
\text { endpoint }\end{array}$ & [38] \\
\hline
\end{tabular}

Abbreviations: $\triangle \mathrm{EGFR}$, mutated epidermal growth factor receptor; Afa, afatinib; Afli, aflibercept; Amplif, amplification; Bev, bevacizumab; Car, carboplatin; Cer, cediranib; Chemo, chemotherapy; Cis, cisplatin; Doc, docetaxel; Gem, gemcitabine; Mot, motesanib; Nin, nintedanib; NR, not reported; NSCLC, non-small cell lung cancer; OS, overall survival; Pac, paclitaxel; PR, partial response, Pem, pemetrexed; PS, performance status; PFS, progression-free survival; RR, response rates; Sor, sorafenib; Sun, sunitinib; Tiv, tivantinib; Van, vandetanib. 
phase III studies that evaluated the drug as a first-line treatment [32,33] while further results are awaited for sunitinib from ongoing trials conducting in a different setting of patients [34].

Other investigational new drugs for the treatment of advanced NCSLC patients are at different stages of development (Table 2). However, most of them have shown controversial results or still have a low level of evidence for efficacy [35-39]. An illustrative example is vandetanib, a multitargeted TKI, which failed to improve OS or PFS in a series of four phase III clinical trials as monotherapy [40] or combined to chemotherapy [36,41, 42] or erlotinib [43]. Based on these negative results, the FDA withdrew its approval in NSCLC. In addition, the administration of most of these drugs has been associated with the occurrence of severe (grade $\geq 3$ ) adverse events. For example, the randomized phase II study that evaluated untreated NSCLC patients receiving either carboplatin/paclitaxel/bevacizumab with or without sunitinib, was not completed due to the poor tolerability of patients to receive the drug (of patients receiving sunitinib, $52 \%$ required treatment interruption and $59 \%$ discontinued the treatment because of adverse events) [44].

\section{New Paradigm for the Treatment of Patients with Advanced NSCLC: The Transition to a Chronic Disease}

Up to date, advanced cancer cannot be cured. However, therapeutic progress is opening the possibility of transforming cancer into a chronic disease compatible with years of good quality of life. This trend is clearly identifiable in lymphoma, prostate, breast and ovarian tumors, where a 5-year survival rates for the advanced disease is moving near 30\% and beyond [45]. Could this be also an attainable goal for advanced NSCLC?

In the last years, a trend to increased survival has been observed in patients with advanced NSCLC with the inclusion of novel therapeutic approaches. From two-year survival rates of $0 \%-10 \%$ with single-agent chemotherapy, the figure improves to $20 \%$ by using platinum doublets. More recently, maintenance with pemetrexed increased up to $25 \%$ [46], a data subsequently enhanced with the use of angiogenesis and EGFR blocking agents and small molecules TKIs. This trend of increased survival in advanced tumors, suggest the possibility to transform advanced cancer into a chronic disease. However, the main drawback of existing drugs for advanced NSCLC treatment is its high toxicity. Most of the approved drugs for advanced NSCLC treatment are highly toxic.

Chemotherapies exert its cytotoxic effects un-specifically, affecting not only tumor cells, but also normal cells and tissues. The up to date approved targeted therapies provokes related adverse events, i.e. drugs targeting the
VEGF system like bevacizumab, are associated with bleeding; and drugs targeting the EGFR system like cetuximab, erlotinib and gefitinib, with skin rash and others adverse events. The use of these drugs is then subjected to patient's tolerability; even when a minority of patients that tolerate these adverse events can receive it under long-term treatments. However, we still need therapy options that can be used chronically in a wider patient population.

The goal of transform advanced cancer into a chronic disease, require therapeutic weapons with low toxicity that could be used chronically. These weapons are provided by biotechnology, with the development of novel specific immunotherapies approaches for cancer treatment. With the availability of these target-specific, nontoxic drugs, such as cancer vaccines, a major change in the management of advanced cancer is foreseen.

Drugs with low toxicity and tolerable by the majority of patients can be administered chronically, without risk of accumulative toxicity, and advanced cancer could be treated as a chronic disease that cannot be cured, but controlled for long time periods, with a good quality of life for the patients [5]. This is not the only case in the history of medicine that a new drug could change the curse of a disease. In fact, diabetes used to be a death sentence until 1922, when the medical researcher Frederick Banting and a colleague, Dr. John Macleod, discovered the insulin [47]. Insulin allowed a therapeutic management of diabetes that makes it a controllable, chronic disease. Cancer vaccines could be thus the "insulin" of cancer patients.

\section{Developing Active Immunotherapy for NSCLC Treatment}

The immune system plays an important role in the interaction between a cancer and its host. Scientists have long understood that tumors can be recognized by a patient's immune system. Rare reports dating back to the 1800 s have documented spontaneous tumor regression after infectious events [48]. Such regressions, however, are usually seen in only very immunogenic tumors, such as renal cell carcinoma and melanoma $[49,50]$. NSCLC is a notoriously non-immunogenic cancer, or a cancer in which we have been unable to trigger an appropriate immune response for multiple reasons; and this characteristic has limited the development of immune therapies for NSCLC [51]. If, however, the immune system can be stimulated to recognize the tumor as an antigen, it can be utilized to specifically attack the tumor. This strategy allows the patient to avoid the toxicities, like myelosupression, neutropenic fever, mucositis, hair loss and gastrointestinal disturbance that arise from indiscriminately destroying all dividing cells with systemic chemotherapy. 
Active-specific immunotherapy is an area of oncology that is rapidly expanding and delivering promising results. Therapeutic vaccines have been developed for the treatment of different types of cancers. For example, Sipuleucel-T is a vaccine in phase III clinical trials that modulates $\mathrm{T}$ cell activity in patients with metastatic melanoma and castrate-resistant prostate cancer $[52,53]$. There is evidence to suggest that a similar approach could be very beneficial to the survival and quality of life of NSCLC patients [54], and has been proposed as a novel method to palliate metastatic and non-operable NSCLC patients and as an adjuvant therapy to surgical resection.

A therapeutic vaccine is composed of one or more tumor antigens, and sometimes with an adjuvant that the immune system recognizes as foreign. Such a vaccine induces a powerful and enduring immune response to the specific tumor antigen(s). Vaccines can either be immune system modulators directed to allow de novo generation of antitumor activity or agents that elicit specific antitumor activity, known as therapeutic cancer vaccines [55]. Therapeutic cancer vaccines are classified in either wholecell vaccines or vaccines that target specific antigens.

Different cancer vaccines has been developed for all stages of NSCLC, being actually in phase III clinical trials (Table 3 and Figure 2) [56,57]; among them, the whole cell vaccine, Belagenpumatucel-L, targeting the TGF- $\beta 2$. There are other vaccines that target specific antigens in cancer cells, including this targeting the melanoma-associated antigen A3 (MAGE-A3), the L-BLP25

Table 3. Phase III clinical trials with therapeutic vaccines in NSCLC.

\begin{tabular}{|c|c|c|c|c|c|}
\hline Trial design & Target & Stage & Study design & Primary end point & Estimated completed date \\
\hline $\begin{array}{l}\text { Belagenpumatucel-L } \\
\text { STOP }(\mathrm{N}=506) \\
\text { Phase III } \\
\text { Completed }\end{array}$ & TGF- $\beta 2$ & IIIa, IIIb or IV & $\begin{array}{l}\text { Vaccine + BSC vs placebo } \\
+ \text { BSC after response to } \\
\text { chemotherapy }\end{array}$ & OS & October 2012 \\
\hline $\begin{array}{l}\text { MAGE-A3 MAGRIT } \\
(\mathrm{N}=2270) \text { Phase III }\end{array}$ & $\begin{array}{l}\text { Melanoma-associated } \\
\text { antigen M3 }\end{array}$ & Ib, II or IIIa & $\begin{array}{l}\text { Resection + chemotherapy } \\
+ \text { vaccine } v s \text { resection } \\
+ \text { vaccine in MAGE A } 3 \\
+ \text { patients }\end{array}$ & DFS & October 2016 [61] \\
\hline $\begin{array}{l}\text { L-BLP25 START } \\
(\mathrm{N}=1476) \text { Phase III }\end{array}$ & MUC 1 protein & IIIb & $\begin{array}{l}\mathrm{L}-\mathrm{BLP} 25+\mathrm{BSC} \text { vs BSC } \\
\text { alone after response to } \\
\text { chemotherapy }\end{array}$ & OS & September 2014 [64] \\
\hline $\begin{array}{l}\text { TG4010 TIME } \\
(\mathrm{N}=1000) \text { Phase III }\end{array}$ & MUC 1 protein & IV & $\begin{array}{l}\text { Chemotherapy }+ \text { TG4010 } \\
\text { vs chemotherapy }+ \text { placebo }\end{array}$ & OS & December 2016 \\
\hline $\begin{array}{l}\text { CIMAvax-EGF }(\mathrm{N}=579) \\
\text { Phase III Completed }\end{array}$ & EGF & IIIb or IV & $\begin{array}{l}\text { CIMAVAX }+ \text { BSC } v s \\
\text { BSC alone after responding } \\
\text { to chemotherapy }\end{array}$ & OS & Completed [83] \\
\hline
\end{tabular}

Abbreviations: BSC, best supportive care; DFS, disease-free survival; OS, overall survival; TGF $\beta 2$, transforming growth factor $\beta 2$.

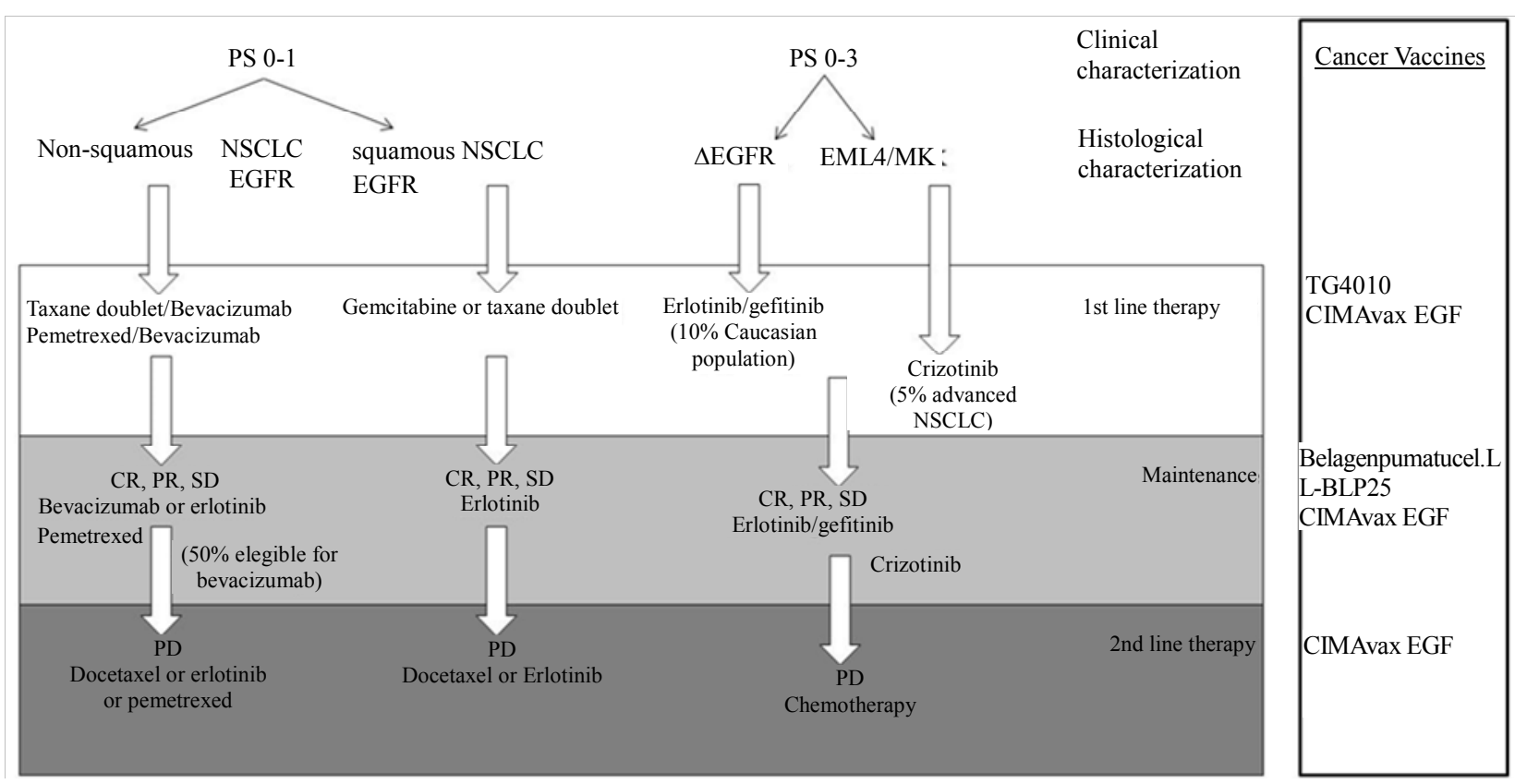

Figure 2. Inclusion of therapeutic cancer vaccines in the current algorithm of treatment of advanced NSCLC patients. 
and TG4010 vaccines that target the Mucin-1 protein. Finally, the CIMAvax EGF vaccine targets EGF and prevents it from binding with its receptor, effectively preventing tumor growth. Each of these vaccines has shown promising results in clinical trials and offers many potential targets for the directed treatment and improved survival of NSCLC patients.

Belagenpumatucel-L is an allogeneic whole cell vaccine that was created from four different NSCLC cell lines, genetically modified to elaborate an antisense oligonucleotide to TGF- $\beta 2$. Because this vaccine was created from multiple cell lines, it has a wide array of antigens and is thus potentially beneficial in most NSCLC patients. In a phase II trial by Nemunaitis, et al, in 2006, 75 NSCLC patients with stage II-IV disease were randomized to receive intradermal injections with one of three different dosage levels of Belagenpumatucel-L [58]. The study revealed that patients who received one of the two higher dosage levels had a significantly improved OS rate relative to the low dosage level $(p=0.0069)$. Moreover, the OS rate of 32.5 months among responders was significantly higher compared to patients who did not respond (OS of 11.6 months; $p=0.011$ ). Belagenpumatucel-L demonstrated minor toxicity with only one grade 3 adverse events [58]. Based on the promising results of the phase II trial, a phase III randomized placebo-controlled clinical trial was designed to assess whether Belagenpumatucel-L can prolong the OS of stage III and IV NSCLC patients by at least three months. To qualify for enrollment, patients must have responded to chemotherapy or had stable disease following a platinum-based chemo regimen. This study has OS as the primary end-point and an estimated enrolled of 506 patients (ClinicalTrials.gov, number NCT00676507). Therefore, in this scenario Belagenpumatucel-L has been tested as maintenance therapy for stages III and IV NSCLC.

MAGE-A3 is a melanoma-associated antigen expressed in a variety of cancers, including $35 \%$ of NSCLC. MAGE-A3 expression is associated with poor prognosis, and its rate of expression increases as the disease progresses $(30 \%$ in stage I NSCLC and $50 \%$ in stage II NSCLC). The MAGE-A3 vaccine is an antigen vaccine that consists of a full-length MAGE-A3 protein complexed to part of the Hemophilus influenzae protein D, packaged with lipid adjuvants. It has been designed for use in the post-operative setting in patients with stage I, II, or IIIa cancer. In patients who have undergone surgical resection, the clinical usefulness of these vaccines is maximized because of the lower post-op tumor burden and the more direct access vaccine has to all tumor cells [59]. In this scenario the MAGE-A3 cancer vaccine is being tested as adjuvant therapy in stages Ib and II NSCLC.

In the phase II trial by Vansteenkiste et al in 2006, 182 MAGE-A3+ patients with surgically resected stage Ib and II NSCLC received induction with 5 doses of either MAGE-A3 $300 \mu \mathrm{g}$ vaccine or placebo every 3 weeks and then maintenance therapy of 8 doses or placebo every 3 months. Follow-up at 28 months revealed improved disease free interval (primary endpoint) in the treatment group (HR; $0.74 ; p=0.107)$. Although these results did not reach statistical significance, a clear survival benefit was observed in this trial. After a median follow-up of 44 months, only $30.3 \%$ of the treatment group experienced relapse, compared to $41.7 \%$ in the control group. The vaccine was well tolerated with only mild flu-like symptoms and injection site reactions [60].

Following the results of the phase II trial, MAGRIT, the largest phase III lung cancer study in history, was designed and is ongoing. MAGRIT is a randomized, double-blinded, placebo-controlled study that evaluates the use of the MAGE-A3 vaccine as adjuvant therapy. The study also compares the efficacy of MAGE-A3 vaccine in participants who underwent resection and adjuvant chemotherapy with a control group who solely underwent resection prior to vaccination. Patients in the study are assigned in a 2:1 ratio to the treatment group vs the placebo group. Five doses are to be administered at 3-week intervals for induction and followed by maintenance therapy with vaccination every 12 weeks. The primary objective is disease-free survival in MAGE-A3 treatment after complete resection. A recent meta-analysis from 25 different randomized trials revealed a pronounced correlation between disease-free survival and OS. The MAGRIT trial is ongoing, with a planned enrollment of 2270 patients, and has an estimated completion date of October 2016 [61].

Mucin 1 (MUC1) is a transmembrane protein normally found on the apical surface of cells. In many malignancies, MUC1 is found to be overexpressed and under-glycosylated or aberrantly glycosylated. MUC1, abnormally expressed in almost half of all NSCLC, has been proven to inhibit physiologic $\mathrm{T}$ cell proliferation. The glycosylation pattern on the abnormally expressed MUC1 in NSCLC makes it an attractive target for immune therapy [62]. L-BLP25 (Stimuvax) is a 20-aminoacid peptide with low-dose cyclophosphamide in a liposomal vehicle. This synthetic vaccine targets the exposed core of MUC1 when aberrantly glycosylated, which induces immune response against the tumor cell. Antigen-specific CTL proliferation and production of IFN- $\gamma$ occur in response to vaccine administration [62].

A randomized phase II trial was conducted by Butts, et $a l$, in 2005 on 171 stage IIIb or IV NSCLC patients after response or SD to first-line chemotherapy [63]. Participants were then randomized to receive either L-BLP25 with best supportive care or, alternatively, best supportive care alone. The primary objective was median OS, which was 17.2 months in the treatment group vs 13.0 
months in the control group (adjusted HR $=0.739 ; p=$ 0.112 ). Although this difference was not statistically significant, a subgroup analysis performed in those patients with stage IIIb locoregional disease $(\mathrm{n}=35)$ showed a more pronounced separation between the treatment and control groups. Stage IIIb NSCLC patients in the treatment group had a median OS of 30.6 months, compared to 13.3 months in the control group (adjusted $\mathrm{HR}=0.524$; $p=0.069$ ) [63]. Common adverse events included mild flu-like symptoms, injection site reactions, and nausea. In patients who received ongoing maintenance therapy, adverse events decreased with time and no long-term safety issues were identified. Although phase II trials with L-BLP25 did not produce statistically significant results, L-BLP25 did seem to benefit patients with stage IIIb NSCLC. These results have prompted a large phase III randomized placebo-controlled clinical trial called START in 1476 patients with unresectable stage III NSCLC and response or stable disease after chemo, randomized 2:1 to receive L-BLP25 with best supportive care or placebo with best supportive care (ClinicalTrials.gov, number NCT00409188). The primary endpoint was OS. Results from this Phase III study initially presented in December 2012 showed that L-BP25 failed to meet its primary endpoint of OS in patients with locally advanced stage III NSCLC. Injection site reactions were seen in $17.3 \%$ in L-BLP25 vs $11.9 \%$ in placebo group, whereas flu-like symptoms were seen in $10.9 \%$ in L-BLP25 vs $9.9 \%$ in placebo [64]. Currently, a second phase III trial, INSPIRE, is being conducted with L-BLP25 in Asian patients suffering from unresectable, stage IIIa or IIIb NSCLC who have had a response or SD after at least two cycles of platinum-based chemo-radiotherapy. Therefore, L-BLP25 is being extensively evaluated as a maintenance therapy in patients with unresectable stage IIIa or IIIb NSCLC.

The TG4010 DNA vaccine also targets the aberrant MUC1 protein. A phase IIb trial by Acres et al., was conducted in 2009 in which 148 untreated MUC1+ patients were randomized to receive cisplatin and gemcitabine, with or without TG4010 [65]. In the experimental group, TG4010 was given every 3 weeks until PD was detected. The primary endpoint was PFS. This endpoint was observed in $44 \%$ of the experimental group vs $35 \%$ in the control group $(p=0.13)$. Based on these results, a phase IIb/III randomized, double-blinded, placebo-controlled trial is now enrolling roughly 1000 patients with stage IV NSCLC. In this study (TIME), participants will either receive chemotherapy with TG4010 or chemotherapy with a placebo until PD is observed. The primary endpoint is OS and the study is estimated to be complete in December 2016. Therefore, the TG4010 cancer vaccine is mainly being tested as a first-line therapy in patients MUC1+ and stage IV NSCLC.

\section{How to Insert Cancer Vaccines in the Existing Arsenal of Therapies for Advanced NSCLC? A Case Example: CIMAvax EGF}

As previously described, cancer vaccines currently in phase III clinical trials are being tested to be included in the algorithm for treatment NSCLC patients either as maintenance, adjuvant or first-line therapy. CIMAvax EGF is a therapeutic cancer vaccine, devoted to create an immune response against the Epidermal Growth Factor (EGF) as specific antibodies that recognize and bind to this protein, with the formation of immune-complexes, eliminated through the kidneys [66-68]. Once eliminated, the EGF cannot exert its physiological action of binding to the EGFR, initial event that unchain cell proliferation mechanisms. It should be noticed that, one of the main characteristics of cancer, is its uncontrolled cell proliferation, mainly due to EGFR overexpression. Elimination of circulating EGF through vaccination with CIMAvax EGF stops the cascade of cell proliferation signals from the very beginning (EGF/EGFR binding). This mechanism of action is basically different from other cancer vaccines devoted to induce the immune system to create cytotoxic responses towards cancer cells.

As compared with other cancer vaccines, CIMAvax EGF has two main strengths in its mechanism of action: firstly, it targets the EGF/EGFR system; which is one of the main current targets for cancer therapy. This system has been validated with different therapeutic approaches such as monoclonal antibodies and small molecules tyrosine kinase inhibitors of demonstrated clinical efficacy in different tumors [69]. Secondly, it has a mechanism of action similar to hormone-deprivation [70]; where the specific anti-EGF antibodies (provoked by vaccination) "castrate" the EGF from circulation, avoiding this growth factor stimulus. The hormone therapy is one of the older and most validated cancer therapies, with demonstrated efficacy, mainly based in deprivation of hormonal stimulus by different procedures [71].

The clinical testing of CIMAvax EGF began in 1995. From there up to date, more than 3000 advanced NSCLC patients had received this vaccine, which has demonstrated immunogenicity, safety, and efficacy (defined as an increase in survival of vaccinate patients as compared with randomized non-vaccinated controls). The vaccine has been applied in different clinical scenarios, making it a versatile product to be inserted in the algorithm of treatments for advanced NSCLC patients (Table 4 and Figure 2).

CIMAvax EGF has been tested in the first-line treatment scenarios for advanced NSCLC patients [72,73]. In a Phase I/II trial, CIMAvax EGF was given before and after standard first-line chemotherapy to patients recently 
Table 4. Summarized results of CIMAvax EGF as first-line, maintenance, and second-line therapy in advanced NSCLC.

\begin{tabular}{|c|c|c|c|c|c|}
\hline Patients & $\begin{array}{l}\text { \% of NSCLC population } \\
\text { amenable to this treatment }\end{array}$ & $\begin{array}{l}\text { Treatment } \\
\text { line }\end{array}$ & Safety & Efficacy & Ref \\
\hline $\begin{array}{l}\text { Advanced } \\
\text { NSCLC } \\
\text { (PS 0-2) }\end{array}$ & $100 \%$ & First line & $\begin{array}{l}\text { Mild or moderated adverse events: } \\
\text { Flu-like, pain at the site } \\
\text { of injection }\end{array}$ & $\begin{array}{l}\text { OS } 12.4 \text { months One-year } \\
\text { survival rate: } 70 \% \text {. }\end{array}$ & {$[72,73]$} \\
\hline $\begin{array}{l}\text { Advanced } \\
\text { NSCLC } \\
\text { (PS 0-2) }\end{array}$ & $100 \%$ & Second line & $\begin{array}{l}\text { Mild or moderated adverse events: } \\
\text { Flu-like, pain at the site } \\
\text { of injection }\end{array}$ & $\begin{array}{l}\text { OS (CIMAvax EGF } v s \text { control): } \\
6.47 \text { vs } 5.33 \text { months } \\
\text { OS in patients who responded to } \\
\text { first-line chemo (CIMAvax EGF } \\
v s \text { control): } 11.57 v s 6.77 \text { months }\end{array}$ & [68] \\
\hline $\begin{array}{l}\text { Advanced } \\
\text { NSCLC } \\
\text { (PS 0-2) }\end{array}$ & $100 \%$ & Maintenance & $\begin{array}{l}\text { Mild or moderated adverse events: } \\
\text { Flu-like, pain at the site } \\
\text { of injection }\end{array}$ & $\begin{array}{l}\text { OS (CIMAvax EGF vs control): } \\
11.2 \text { vs } 7.7 \text { months } \\
\text { Survival rate at } 6 ; 24 ; \text { and } 48 \\
\text { months: } 73 \% ; 27 \% \text { and } 19 \% \\
\text { vs } 72 \% ; 14 \% \text { and } 4 \%\end{array}$ & [83] \\
\hline
\end{tabular}

Abbreviations: NSCLC, non-small cell lung cancer; OS, overall survival; PS, performance status.

diagnosed with advanced (stages IIIb and IV) NSCLC $[72,73]$. Two vaccinations were given before the beginning of chemotherapy; with subsequent monthly vaccinetions after concluding chemotherapy.

Chemotherapy and active immunotherapy are generally regarded as unrelated or even mutually exclusive in cancer treatment, due to chemotherapy-induced immune suppression, dampening the therapeutic efficacy of further active immunotherapies. This trial design giving vaccine-chemotherapy-vaccine was devoted to search the best combination between CIMAvax EGF and chemotherapy. The rationale of this combination was based on studies of homeostatic lymphocyte repopulation after chemotherapy, done by Mckal et al. [74-77]. That group reported the recovery of lymphocytes from the expansion of the peripheral pool (including memory cells) rather than de novo naive cells exported from bone marrow $[78,79]$. This vaccination scheme increased the anti-EGF antibody response, with titers 20 -folds higher, when vaccination was applied after chemotherapy. It was also observed that anti-EGF antibody titers reached during the induction period before chemotherapy did not decreased during the cytotoxic treatment. That means the effect of vaccination is prolonged on time.

There was not influence of previous vaccination in the expected response to chemotherapy. In 20 patients evaluated for objective responses, 2 complete responses and 5 partial responses were observed, for an objective response rate of $35 \%$. Five out of the responses appeared at the end of chemotherapy, but, interestingly, 2 responses occurred during the second vaccination period (V-Ch-V). Additionally, 10 patients reached disease stabilization for a disease control rate of $85 \%$. Moreover, the mean survival was 18.74 months (median 12.4 months), and a 1-year survival rate of $70 \%$. Chemotherapy-related adverse events were not influenced by previous vaccination. Vaccine-related adverse events consisted of mild to moderated flu-like symptoms and pain at the site of injection; as previously described when the
CIMAvax EGF has been administered under different schemes of vaccination $[67,72,80-82]$. This trial demonstrated the feasibility of using CIMAvax EGF in the first-line treatment for advanced NSCLC patients with PS 0-2, independently of their molecular and histological characterization.

CIMAvax EGF has also been tested as second-line therapy [68]. In a phase II clinical trial, 80 patients with advanced stages (IIIb and IV) NSCLC, after finishing first-line chemotherapy, were randomized to receive CIMAvax EGF or best supportive care. Patients were included in the trial independently of their response or not to the first-line treatment: patients with objective response, stable disease or progressive disease after chemotherapy were vaccinated and evaluated for vaccine efficacy based on OS. Vaccination was safe and adverse events were observed in less than $25 \%$ of cases and were grade 1 or 2 according to National Cancer Institute Common Toxicity Criteria (CTC). In this trial OS was measured since one month after concluding first-line chemotherapy. In this scenario, vaccinated patients had a mean survival of 12.73 months (median 6.47 months) whereas the control arm survival was 8.52 months (median 5.33 months). In addition, in those patients who responded to first-line chemotherapy, the mean survival was of 22.45 months (median 11.57 months) whereas responding control patients had a mean survival of 9.32 months (median 6.77 months) [68]. Therefore, CIMAvax EGF in a second-line scenario (after first-line chemotherapy), benefits advanced NSCLC patients with PS 0-2, independently of their molecular and histological characterization. There is a trend of increased benefit in patients that respond to first-line chemotherapy.

CIMAvax EGF has also been tested in a phase III trial in patients that respond to first-line chemotherapy and receive the vaccine as maintenance therapy until and beyond disease progression [83]. In this scenario, patients who responded to first-line chemotherapy were randomized to receive CIMAvax EGF or best supportive 
care. As previously demonstrated, vaccination was safe and not severe-adverse events related with vaccination were observed. In a statistically planned partial cut-off in results, vaccinated patients survived significantly more that not vaccinated controls. Survival times considered from diagnose, had a median of 11.2 months for vaccinated patients (mean 20.6 months) whereas a median of 7.7 months was observed for not vaccinated controls (mean 14.1 months). Survival rates at 6-month, 24month and 48 -month were $73 \%, 27 \%$ and $19 \%$, respectively for the vaccinated group; while $72 \%, 14 \%$ and $4 \%$ for the control group. Vaccination with CIMAvax EGF as maintenance therapy in patients who respond to firstline chemotherapy provides benefit to advanced NSCLC patients with PS 0-2, independently of their molecular and histological characterization.

After its regulatory registration, CIMAvax EGF has been tested in open population both, in Cuba (Phase IV trial) and in Peru. This patient population is mainly composed by patients that received all possible oncospecific treatment and are in disease progression. Up to date 1080 cuban patients received CIMAvax EGF in a Phase IV trial performed at primary attention level. This vaccinated patient population has showed a median overall survival of 14.16 months. According to the National Register of Cancer (2002-2007), advanced NSCLC patients in Cuba have a median survival of 9.6 months. In the 2012 ASCO meeting, it was presented the post-marketing experience with application of CIMAvax EGF in 12 metastatic NSCLC patients that progressed after first-line therapy; the patients received the vaccine alone or in combination with chemotherapy. Vaccination was safe (not adverse events grade III or IV were reported) and produced a clinical benefit associated with improves of OS (18.8 months) and PFS (7.3 months).

An ongoing clinical trial is applying CIMAvax EGF to patients unfit for onco-specific therapies. These patients do not meet the criteria for receiving currently available therapies or they simply refuse to receive other therapy (mainly due to toxicity). The patient population unfit for onco-specific treatments is not small. It has been reported that $30 \%$ of advanced stages NSCLC patients with PS 0-1 unfit chemotherapy; a figure that increase substantially in patients with PS 2-3 [84]. These patients can receive CIMAvax EGF without additional toxicity. Considering this clinical experience, CIMAvax EGF can be inserted in the algorithm for treatment of advanced NSCLC in different scenarios: first-line, second-line and maintenance; the updated clinical experience demonstrates the feasibility of combining it with other available treatments as well as in patients unfit for other therapies. There is not a known limit for CIMAvax EGF application. All advanced NSCLC patients, independently of their PS, their histologic sub-group or their molecular markers characterization (gene mutations or others), are amenable to receive and benefit from this cancer vaccine.

\section{General Discussion}

Patients with NSCLC face a dismal prognosis at the time of diagnosis due to an advanced and aggressive disease, coupled with the limited available treatment options. The treatment of advanced lung cancer has started to make a plateau during the last two decades. After the introduction of platinum doublets, and later on the concept of maintenance treatment with pemetrexed, cytotoxic chemotherapy has not delivered a major advance. A lot of hope has been put on molecular stratification according to specific mutations and drugs that target them. However, the very same results of targeted therapy, no matter how impressive they are for specific patients niches, are showing a major limitation: as a consequence of the specificity of the target, they usually show early resistance. Seemingly, second-generation products will not change this scenario dramatically.

The current challenge is try to transform advanced cancer from a terminal, untreatable disease into a chronic disease that could be controlled for a long time keeping patients with a good quality of life. That implies a complete change in the management of advanced cancer, introducing in the current algorithms of treatments new products that, because of their low toxicity, can be given chronically or even in combination with other existing therapies without significantly increasing toxicity. The need of a treatment, which is endowed with amplification mechanisms, targeted diverse cell populations at the same time, and co-evolved with the tumor cell population itself, has switched the attention again towards active immunotherapy. Therapeutic cancer vaccines should be introduced in the complex therapeutic algorithm early enough to profit the partial remissions or disease stabilizations induced by chemotherapy or targeted therapies, and to have time to boost the host antitumor immune reaction. Early studies of active immunotherapy agents developed for treating NSCLC patients have exhibited promising results, especially in advanced disease where the OS rate has been, historically, very grim. While therapeutic vaccination may not be a panacea, it could be served as a vital adjunct to traditional surgical and chemotherapeutic treatment regimens as we see in the case of the MAGE 3 vaccine for adjuvant therapy or in the case of CIMAvax EGF when it is used in combination with chemotherapy in advanced disease patients.

The identification of better antigenic targets, addition of immune-stimulating adjuvants, and production of improved delivery mechanisms have resulted in a group of vaccines that appear to elicit an effective immune response against tumor cells. This has been a major change in the area of cancer immunology where lung cancer 
vaccines have never been a popular topic. Phase II studies show that these vaccines can produce statistically significant improvements in the PFS or OS for patients, irrespective of the stage of the patient's disease. These vaccines have demonstrated low toxicity together with improved survival and an enhanced quality of life relative to the baseline prognosis. As a result of these studies, for first time in the history of lung cancer and immunotherapy, several phase III trials are ongoing to examine the efficacy of therapeutic vaccination in a larger number of patients with all stages of NSCLC and in different therapeutic scenarios. Some of these vaccines have shown in the clinical setting that their effects are independent of patient's characteristics (tumor histology and presence of driver mutations). This is the case of CIMAvax EGF, which is applicable not only to all advanced NSCLC patients, but also in different lines of the treatment (as first-line, maintenance and second-line therapy).

The mild toxicity of cancer vaccines makes them useful for chronic application and then, it is more probable to accomplish the challenge of converting advanced cancer into a chronic disease. The inclusion of cancer vaccines, alone or combined with other approved therapies, in the current algorithm of advanced NSCLC treatment should represent a major change in the clinical outcome of the disease.

\section{REFERENCES}

[1] J. Ferlay, H. R. Shin, F. Bray, D. Forman, C. Mathers and D. M. Parkin, "Estimates of Worldwide Burden of Cancer in 2008: GLOBOCAN 2008," International Journal of Cancer, Vol. 127, No. 12, 2010, pp. 2893-2917. doi:10.1002/ijc. 25516

[2] A. Jemal, F. Bray, M. M. Center, J. Ferlay, E. Ward and D. Forman, "Global Cancer Statistics," CA: A Cancer Journal for Clinicians, Vol. 61, No. 2, 2011, pp. 69-90. doi:10.3322/caac.20107

[3] J. R. Molina, P. Yang, S. D. Cassivi, S. E. Schild and A. A. Adjei, "Non-Small Cell Lung Cancer: Epidemiology, Risk Factors, Treatment, and Survivorship," Mayo Clinic Proceedings, Vol. 83, No. 5, 2008, pp. 584-594.

[4] R. Rosell, M. Skrzypski, E. Jassem, M. Taron, R. Bartolucci, J. J. Sanchez, et al., "BRCA1: A Novel Prognostic Factor in Resected Non-Small-Cell Lung Cancer," PLoS One, Vol. 2, No. 11, 2007, p. e1129.

doi:10.1371/journal.pone.0001129

[5] G. Gonzalez, T. Crombet and A. Lage, "Chronic Vaccination with a Therapeutic EGF-Based Cancer Vaccine: A Review of Patients Receiving Long Lasting Treatment," Current Cancer Drug Targets, Vol. 11, No. 1, 2011, pp. 103-110. doi:10.2174/156800911793743583

[6] A. Lage and T. Crombet, "Control of Advanced Cancer: The Road to Chronicity," International Journal of Environmental Research and Public Health, Vol. 8, No. 3, 2011, pp. 683-697. doi:10.3390/ijerph8030683
[7] G. D'Addario, M. Pintilie, N. B. Leighl, R. Feld, T. Cerny and F. A. Shepherd, "Platinum-Based versus NonPlatinum-Based Chemotherapy in Advanced Non-SmallCell Lung Cancer: A Meta-Analysis of the Published Literature," Journal of Clinical Oncology, Vol. 23, No. 13, 2005, pp. 2926-2936. doi:10.1200/JCO.2005.03.045

[8] A. Sandler, R. Gray, M. C. Perry, J. Brahmer, J. H. Schiller, A. Dowlati, et al., "Paclitaxel-Carboplatin Alone or with Bevacizumab for Non-Small-Cell Lung Cancer," New England Journal of Medicine, Vol. 355, No. 24, 2006, pp. 2542-2550. doi:10.1056/NEJMoa061884

[9] R. Rosell, E. Carcereny, R. Gervais, A. Vergnenegre, B. Massuti, E. Felip, et al., "Erlotinib versus Standard Chemotherapy as First-Line Treatment for European Patients with Advanced EGFR Mutation-Positive Non-Small-Cell Lung Cancer (EURTAC): A Multicentre, Open-Label, Randomised Phase 3 Trial," Lancet Oncology, Vol. 13, No. 3, 2012, pp. 239-246. doi:10.1016/S1470-2045(11)70393-X

[10] A. Inoue, K. Kobayashi, M. Maemondo, S. Sugawara, S. Oizumi, H. Isobe, et al., "Updated Overall Survival Results from a Randomized Phase III Trial Comparing Gefitinib with Carboplatin-Paclitaxel for Chemo-Naive NonSmall Cell Lung Cancer with Sensitive EGFR Gene Mutations (NEJ002)," Annals of Oncology, Vol. 24, No. 1, 2013, pp. 54-59. doi:10.1093/annonc/mds214

[11] D. R. Camidge, Y. J. Bang, E. L. Kwak, A. J. Iafrate, M. Varella-Garcia, S. B. Fox, et al., "Activity and Safety of Crizotinib in Patients with ALK-Positive Non-Small-Cell Lung Cancer: Updated Results from a Phase 1 Study," Lancet Oncology, Vol. 13, No. 10, 2012, pp. 1011-1019. doi:10.1016/S1470-2045(12)70344-3

[12] L. Paz-Ares, F. de Marinis, M. Dediu, M. Thomas, J. L. Pujol, P. Bidoli, et al., "Maintenance Therapy with Pemetrexed plus Best Supportive Care versus Placebo plus Best Supportive Care after Induction Therapy with Pemetrexed plus Cisplatin for Advanced Non-Squamous Non-Small-Cell Lung Cancer (PARAMOUNT): A Double-Blind, Phase 3, Randomised Controlled Trial," Lancet Oncology, Vol. 13, No. 3, 2012, pp. 247-255. doi:10.1016/S1470-2045(12)70063-3

[13] T. Ciuleanu, T. Brodowicz, C. Zielinski, J. H. Kim, M. Krzakowski, E. Laack, et al., "Maintenance Pemetrexed plus Best Supportive Care versus Placebo plus Best Supportive Care for Non-Small-Cell Lung Cancer: A Randomised, Double-Blind, Phase 3 Study," Lancet, Vol. 374, No. 9699,2009 , pp. 1432-1440. doi:10.1016/S0140-6736(09)61497-5

[14] P. M. Fidias, S. R. Dakhil, A. P. Lyss, D. M. Loesch, D. M. Waterhouse, J. L. Bromund, et al., "Phase III Study of Immediate Compared with Delayed Docetaxel after FrontLine Therapy with Gemcitabine plus Carboplatin in Advanced Non-Small-Cell Lung Cancer," Journal of Clinical Oncology, Vol. 27, No. 4, 2009, pp. 591-598. doi:10.1200/JCO.2008.17.1405

[15] M. Perol, C. Chouaid, D. Perol, F. Barlesi, R. Gervais, V. Westeel, et al., "Randomized, Phase III Study of Gemcitabine or Erlotinib Maintenance Therapy versus Observation, with Predefined Second-Line Treatment, after Cisplatin-Gemcitabine Induction Chemotherapy in Advanced 
Non-Small-Cell Lung Cancer," Journal of Clinical Oncology, Vol. 30, No. 28, 2012, pp. 3516-3524. doi:10.1200/JCO.2011.39.9782

[16] F. V. Fossella, "Docetaxel for Previously Treated NonSmall-Cell Lung Cancer," Oncology (Williston Park), Vol. 16, No. 6, 2002, pp. 45-51.

[17] F. A. Shepherd, "Second-Line Chemotherapy for NonSmall Cell Lung Cancer," Expert Review of Anticancer Therapy, Vol. 3, No. 4, 2003, pp. 435-442. doi:10.1586/14737140.3.4.435

[18] F. A. Shepherd, J. Rodrigues Pereira, T. Ciuleanu, E. H. Tan, V. Hirsh, S. Thongprasert, et al., "Erlotinib in Previously Treated Non-Small-Cell Lung Cancer," New England Journal of Medicine, Vol. 353, No. 2, 2005, pp. 123132. doi:10.1056/NEJMoa050753

[19] A. Belalcazar, D. Azana, C. A. Perez, L. E. Raez and E. S. Santos, "Targeting the Met Pathway in Lung Cancer," Expert Review of Anticancer Therapy, Vol. 12, No. 4, 2012, pp. 519-528. doi:10.1586/era.12.16

[20] G. J. Riely, K. A. Politi, V. A. Miller and W. Pao, "Update on Epidermal Growth Factor Receptor Mutations in Non-Small Cell Lung Cancer," Clinical Cancer Research, Vol. 12, No. 24, 2006, pp. 7232-7241. doi:10.1158/1078-0432.CCR-06-0658

[21] M. Maemondo, A. Inoue, K. Kobayashi, S. Sugawara, S. Oizumi, H. Isobe, et al., "Gefitinib or Chemotherapy for Non-Small-Cell Lung Cancer with Mutated EGFR," New England Journal of Medicine, Vol. 362, No. 25, 2010, pp. 2380-2388. doi:10.1056/NEJMoa0909530

[22] E. L. Kwak, R. Sordella, D. W. Bell, N. Godin-Heymann, R. A. Okimoto, B. W. Brannigan, et al., "Irreversible Inhibitors of the EGF Receptor May Circumvent Acquired Resistance to Gefitinib," Proceedings of the National Academy of Sciences of the United States of America, Vol. 102 , No. 21, 2005, pp. 7665-7670. doi:10.1073/pnas.0502860102

[23] V. Nelson, J. Ziehr, M. Agulnik and M. Johnson, “Afatinib: Emerging Next-Generation Tyrosine Kinase Inhibitor for NSCLC," OncoTargets and Therapy, Vol. 6, No. 2013, pp. 135-143.

[24] J. C. Yang, J. Y. Shih, W. C. Su, T. C. Hsia, C. M. Tsai, S. H. Ou, et al., "Afatinib for Patients with Lung Adenocarcinoma and Epidermal Growth Factor Receptor Mutations (LUX-Lung 2): A Phase 2 Trial," Lancet Oncology, Vol. 13 , No. 5, 2012, pp. 539-548. doi:10.1016/S1470-2045(12)70086-4

[25] L. V. Sequist, J. C. Yang, N. Yamamoto, K. O’Byrne, V. Hirsh, T. Mok, et al., "Phase III Study of Afatinib or Cisplatin Plus Pemetrexed in Patients with Metastatic Lung Adenocarcinoma with EGFR Mutations," Journal of Clinical Oncology, 2013.

[26] V. A. Miller, V. Hirsh, J. Cadranel, Y. M. Chen, K. Park, S. W. Kim, et al., "Afatinib versus Placebo for Patients with Advanced, Metastatic Non-Small-Cell Lung Cancer after Failure of Erlotinib, Gefitinib, or Both, and One or Two Lines of Chemotherapy (LUX-Lung 1): A Phase 2b/3 Randomised Trial," Lancet Oncology, Vol. 13, No. 5, 2012, pp. 528-538. doi:10.1016/S1470-2045(12)70087-6

[27] J. A. Engelman, K. Zejnullahu, T. Mitsudomi, Y. Song, C.
Hyland, J. O. Park, et al., "MET Amplification Leads to Gefitinib Resistance in Lung Cancer by Activating ERBB3 Signaling," Science, Vol. 316, No. 5827, 2007, pp. 1039-1043. doi:10.1126/science. 1141478

[28] L. V. Sequist, J. von Pawel, E. G. Garmey, W. L. Akerley, W. Brugger, D. Ferrari, et al., "Randomized Phase II Study of Erlotinib plus Tivantinib versus Erlotinib plus Placebo in Previously Treated Non-Small-Cell Lung Cancer," Journal of Clinical Oncology, Vol. 29, No. 24, 2011, pp. 3307-3315. doi:10.1200/JCO.2010.34.0570

[29] G. V. Scagliotti, S. Novello, J. H. Schiller, V. Hirsh, L. V. Sequist, J. C. Soria, et al., "Rationale and Design of MARQUEE: A Phase III, Randomized, Double-Blind Study of Tivantinib plus Erlotinib versus Placebo plus Erlotinib in Previously Treated Patients with Locally Advanced or Metastatic, Nonsquamous, Non-Small-Cell Lung Cancer," Clinical Lung Cancer, Vol. 13, No. 5, 2012, pp. 391-395. doi:10.1016/j.cllc.2012.01.003

[30] M. H. Cohen, J. Gootenberg, P. Keegan and R. Pazdur, "FDA Drug Approval Summary: Bevacizumab (Avastin) plus Carboplatin and Paclitaxel as First-Line Treatment of Advanced/Metastatic Recurrent Nonsquamous Non-Small Cell Lung Cancer," Oncologist, Vol. 12, No. 6, 2007, pp. 713-718. doi:10.1634/theoncologist.12-6-713

[31] V. Velcheti, A. Viswanathan and R. Govindan, "The Proportion of Patients with Metastatic Non-Small Cell Lung Cancer Potentially Eligible for Treatment with Bevacizumab: A Single Institutional Survey," Journal of Thoracic Oncology, Vol. 1, No. 5, 2006, p. 501. doi:10.1097/01243894-200606000-00023

[32] G. Scagliotti, S. Novello, J. von Pawel, M. Reck, J. R. Pereira, M. Thomas, et al., "Phase III Study of Carboplatin and Paclitaxel Alone or with Sorafenib in Advanced Non-Small-Cell Lung Cancer," Journal of Clinical Oncology, Vol. 28, No. 11, 2010, pp. 1835-1842. doi:10.1200/JCO.2009.26.1321

[33] L. G. Paz-Ares, B. Biesma, D. Heigener, J. von Pawel, T. Eisen, J. Bennouna, et al., "Phase III, Randomized, Double-blind, Placebo-Controlled Trial of Gemcitabine/Cisplatin Alone or with Sorafenib for the First-Line Treatment of Advanced, Nonsquamous Non-Small-Cell Lung Cancer," Journal of Clinical Oncology, Vol. 30, No. 25, 2012, pp. 3084-3092. doi:10.1200/JCO.2011.39.7646

[34] M. Majem and C. Pallares, "An Update on Molecularly Targeted Therapies in Second- and Third-Line Treatment in Non-Small Cell Lung Cancer: Focus on EGFR Inhibitors and Anti-Angiogenic Agents," Clinical and Translational Oncology, Vol. 15, No. 5, 2013, pp. 343-357. doi:10.1007/s12094-012-0964-2

[35] R. Ramlau, V. Gorbunova, T. E. Ciuleanu, S. Novello, M. Ozguroglu, T. Goksel, et al., "Aflibercept and Docetaxel versus Docetaxel alone after Platinum Failure in Patients with Advanced or Metastatic Non-Small-Cell Lung Cancer: A Randomized, Controlled Phase III Trial," Journal of Clinical Oncology, Vol. 30, No. 29, 2012, pp. 36403647. doi:10.1200/JCO.2012.42.6932

[36] R. H. de Boer, O. Arrieta, C. H. Yang, M. Gottfried, V. Chan, J. Raats, et al., "Vandetanib plus Pemetrexed for the Second-Line Treatment of Advanced Non-Small-Cell Lung Cancer: A Randomized, Double-Blind Phase III 
Trial," Journal of Clinical Oncology, Vol. 29, No. 8, 2011, pp. 1067-1074. doi:10.1200/JCO.2010.29.5717

[37] G. D. Goss, A. Arnold, F. A. Shepherd, M. Dediu, T. E. Ciuleanu, D. Fenton, et al., "Randomized, Double-Blind Trial of Carboplatin and Paclitaxel with Either Daily Oral Cediranib or Placebo in Advanced Non-Small-Cell Lung Cancer: NCIC Clinical Trials Group BR24 Study," Journal of Clinical Oncology, Vol. 28, No. 1, 2010, pp. 49-55. doi:10.1200/JCO.2009.22.9427

[38] G. R. Blumenschein Jr., F. Kabbinavar, H. Menon, T. S. Mok, J. Stephenson, J. T. Beck, et al., "A Phase II, Multicenter, Open-Label Randomized Study of Motesanib or Bevacizumab in Combination with Paclitaxel and Carboplatin for Advanced Nonsquamous Non-Small-Cell Lung Cancer," Annals of Oncology, Vol. 22, No. 9, 2011, pp. 2057-2067. doi:10.1093/annonc/mdq731

[39] G. V. Scagliotti, I. Vynnychenko, K. Park, Y. Ichinose, K. Kubota, F. Blackhall, et al., "International, Randomized, Placebo-Controlled, Double-Blind Phase III Study of Motesanib plus Carboplatin/Paclitaxel in Patients with Advanced Nonsquamous Non-Small-Cell Lung Cancer: MONET1," Journal of Clinical Oncology, Vol. 30, No. 23, 2012, pp. 2829-2836. doi:10.1200/JCO.2011.41.4987

[40] A. Morabito, M. C. Piccirillo, R. Costanzo, C. Sandomenico, G. Carillio, G. Daniele, et al., "Vandetanib: An Overview of Its Clinical Development in NSCLC and Other Tumors," Drugs Today, Vol. 46, No. 9, 2010, pp. 683-698. doi:10.1358/dot.2010.46.9.1516989

[41] R. B. Natale, D. Bodkin, R. Govindan, B. G. Sleckman, N. A. Rizvi, A. Capo, et al., "Vandetanib versus Gefitinib in Patients with Advanced Non-Small-Cell Lung Cancer: Results from a Two-Part, Double-Blind, Randomized Phase ii Study," Journal of Clinical Oncology, Vol. 27, No. 15, 2009, pp. 2523-2529. doi:10.1200/JCO.2008.18.6015

[42] R. S. Herbst, Y. Sun, W. E. Eberhardt, P. Germonpre, N. Saijo, C. Zhou, et al., "Vandetanib plus Docetaxel versus Docetaxel as Second-Line Treatment for Patients with Advanced Non-Small-Cell Lung Cancer (ZODIAC): A Double-Blind, Randomised, Phase 3 Trial," The Lancet Oncology, Vol. 11, No. 7, 2010, pp. 619-626. doi:10.1016/S1470-2045(10)70132-7

[43] R. B. Natale, S. Thongprasert, F. A. Greco, M. Thomas, C. M. Tsai, P. Sunpaweravong, et al., "Phase III Trial of Vandetanib Compared with Erlotinib in Patients with Previously Treated Advanced Non-Small-Cell Lung Cancer," Journal of Clinical Oncology, Vol. 29, No. 8, 2011, pp. 1059-1066. doi:10.1200/JCO.2010.28.5981

[44] M. A. Socinski, F. A. Scappaticci, M. Samant, M. M. Kolb and M. F. Kozloff, "Safety and Efficacy of Combining Sunitinib with Bevacizumab + Paclitaxel/Carboplatin in Non-Small Cell Lung Cancer," Journal of Thoracic Oncology, Vol. 5, No. 3, 2010, pp. 354-360. doi:10.1097/JTO.0b013e3181c7307e

[45] A. Jemal, R. Siegel, J. Xu and E. Ward, "Cancer Statistics, 2010," CA: A Cancer Journal for Clinicians, Vol. 60, No. 5, 2010, pp. 277-300. doi:10.3322/caac. 20073

[46] C. Gerard and C. Debruyne, "Immunotherapy in the Landscape of New Targeted Treatments for Non-Small
Cell Lung Cancer," Molecular Oncology, Vol. 3, No. 5-6, 2009, pp. 409-424. doi:10.1016/j.molonc.2009.09.001

[47] J. J. Macleod, "Insulin and Diabetes: A General Statement of the Physiological and Therapeutic Effects of Insulin," British Medical Journal, Vol. 2, No. 3227, 1922, pp. 833-835. doi:10.1136/bmj.2.3227.833

[48] H. C. Nauts, "Bacteria and Cancer-Antagonisms and Benefits," Journal of Cancer Survivorship, Vol. 8, No. 4, 1989, pp. 713-723.

[49] E. M. Jaffee and D. M. Pardoll, "Murine Tumor Antigens: Is It Worth the Search?" Current Opinion in Immunology, Vol. 8, No. 5, 1996, pp. 622-627. doi:10.1016/S0952-7915(96)80077-X

[50] D. I. Papac, J. B. Briggs, E. T. Chin and A. J. Jones, “A High-Throughput Microscale Method to Release NLinked Oligosaccharides from Glycoproteins for MatrixAssisted Laser Desorption/Ionization Time-of-Flight Mass Spectrometric Analysis," Glycobiology, Vol. 8, No. 5, 1998, pp. 445-454. doi:10.1093/glycob/8.5.445

[51] V. G. Brichard and D. Lejeune, "Cancer Immunotherapy Targeting Tumour-Specific Antigens: Towards a New Therapy for Minimal Residual Disease," Expert Opinion on Biological Therapy, Vol. 8, No. 7, 2008, pp. 951-968. doi:10.1517/14712598.8.7.951

[52] P. W. Kantoff, C. S. Higano, N. D. Shore, E. R. Berger, E. J. Small, D. F. Penson, et al., "Sipuleucel-T Immunotherapy for Castration-Resistant Prostate Cancer," The New England Journal of Medicine, Vol. 363, No. 5, 2010, pp. 411-422. doi:10.1056/NEJMoa1001294

[53] C. Robert, L. Thomas, I. Bondarenko, S. O’Day, D. J. M, C. Garbe, et al., "Ipilimumab plus Dacarbazine for Previously Untreated Metastatic Melanoma," The New England Journal of Medicine, Vol. 364, No. 26, 2011, pp. 2517-2526. doi:10.1056/NEJMoa1104621

[54] C. A. Perez, E. S. Santos and L. E. Raez, "Active Immunotherapy for Non-Small-Cell Lung Cancer: Moving Toward a Reality," Expert Review of Anticancer Therapy, Vol. 11, No. 10, 2011, pp. 1599-1605. doi:10.1586/era.11.155

[55] M. Reck, "What Future Opportunities May ImmunoOncology Provide for Improving the Treatment of Patients with Lung Cancer?" Annals of Oncology, Vol. 23, Suppl. 8, 2012, pp. 28-34.

[56] L. Decoster, I. Wauters and J. F. Vansteenkiste, "Vaccination Therapy for Non-Small-Cell Lung Cancer: Review of Agents in Phase III Development," Annals of Oncology, Vol. 23, No. 6, 2012, pp. 1387-1393. doi:10.1093/annonc/mdr564

[57] A. Thomas and R. Hassan, "Immunotherapies for NonSmall-Cell Lung Cancer and Mesothelioma," The Lancet Oncology, Vol. 13, No. 7, 2012, pp. e301-e310. doi:10.1016/S1470-2045(12)70126-2

[58] J. Nemunaitis, R. O. Dillman, P. O. Schwarzenberger, N. Senzer, C. Cunningham, J. Cutler, et al., "Phase II Study of Belagenpumatucel-L, a Transforming Growth Factor Beta-2 Antisense Gene-Modified Allogeneic Tumor Cell Vaccine in Non-Small-Cell Lung Cancer," Journal of Clinical Oncology, Vol. 24, No. 29, 2006, pp. 4721-4730. doi:10.1200/JCO.2005.05.5335 
[59] W. Sienel, C. Varwerk, A. Linder, D. Kaiser, M. Teschner, M. Delire, et al., "Melanoma Associated Antigen (MAGE)-A3 Expression in Stages I and II Non-Small Cell Lung Cancer: Results of a Multi-Center Study," European Journal Cardio-Thoracic Surgery, Vol. 25, No. 1, 2004, pp. 131-134. doi:10.1016/j.ejcts.2003.09.015

[60] J. Vansteenkiste, M. Zielinski, A. Linder, J. Dahabreh, E. E. Gonzalez, W. Malinowski, et al., "Adjuvant MAGEA3 Immunotherapy in Resected Non-Small-Cell Lung Cancer: Phase II Randomized Study Results," Journal of Clinical Oncology, Vol. 31, No. 19, 2013, pp. 2396-2403. doi:10.1200/JCO.2012.43.7103

[61] P. Tyagi and B. Mirakhur, "MAGRIT: The Largest-Ever Phase III Lung Cancer Trial Aims to Establish a Novel Tumor-Specific Approach to Therapy," Clinical Lung Cancer, Vol. 10, No. 5, 2009, pp. 371-374. doi:10.3816/CLC.2009.n.052

[62] D. Raina, M. Kosugi, R. Ahmad, G. Panchamoorthy, H. Rajabi, M. Alam, et al., "Dependence on the MUC1-C Oncoprotein in Non-Small Cell Lung Cancer Cells," Molecular Cancer Therapeutics, Vol. 10, No. 5, 2011, pp. 806-816. doi:10.1158/1535-7163.MCT-10-1050

[63] C. Butts, N. Murray, A. Maksymiuk, G. Goss, E. Marshall, D. Soulieres, et al., "Randomized Phase IIB Trial of BLP25 Liposome Vaccine in Stage IIIB and IV NonSmall-Cell Lung Cancer," Journal of Clinical Oncology, Vol. 23, No. 27, 2005, pp. 6674-6681. doi:10.1200/JCO.2005.13.011

[64] C. Butts, M. Socinski, P. Mitchell, N. Thatcher, L. Havel, M. Krzakowski, et al., "START: A Phase III Study of L-BLP25 Cancer Immunotherapy for Unresectable Stage III Non-Small Cell Lung Cancer," ASCO Annual Meeting, Chicago, 2013.

[65] E. Quoix, R. Ramlau, V. Westeel, Z. Papai, A. Madroszyk, A. Riviere, et al., "Therapeutic Vaccination with TG4010 and First-Line Chemotherapy in Advanced NonSmall-Cell Lung Cancer: A Controlled Phase 2B Trial," The Lancet Oncology, Vol. 12, No. 12, 2011, pp. 11251133. doi:10.1016/S1470-2045(11)70259-5

[66] G. González, B. Sánchez, E. Suárez, I. Beausoleil, O. Pérez, M. Lastre, et al., "Induction of Immune Recognition of Self Epidermal Growth Factor (EGF): Effect on EGF-Biodistribution and Tumor Growth," Vaccine Research, Vol. 5, No. 4, 1996, pp. 233-244.

[67] T. C. Ramos, E. N. Vinageras, M. C. Ferrer, B. G. Verdecia, I. L. Rupale, L. M. Perez, et al., "Treatment of NSCLC Patients with an EGF-Based Cancer Vaccine: Report of a Phase I Trial," Cancer Biology \& Therapy, Vol. 5, No. 2, 2006, pp. 145-149. doi:10.4161/cbt.5.2.2334

[68] E. Neninger-Vinageras, A. de la Torre, M. Osorio Rodriguez, M. Catala Ferrer, I. Bravo, M. M. del Pino, et al., "Phase II Randomized Controlled Trial of an Epidermal Growth Factor Vaccine in Advanced Non-Small-Cell Lung Cancer," Journal of Clinical Oncology, Vol. 26, No. 9, 2008, pp. 1452-1458. doi:10.1200/JCO.2007.11.5980

[69] Y. Yarden and G. Pines, "The ERBB Network: At Last, Cancer Therapy Meets Systems Biology," Nature Reviews Cancer, Vol. 12, No. 8, 2012, pp. 553-563.
[70] G. Gonzalez and A. Lage, "Cancer Vaccines for Hormone/Growth Factor Immune Deprivation: A Feasible Approach for Cancer Treatment," Current Cancer Drug Targets, Vol. 7, No. 3, 2007, pp. 229-241. doi: $10.2174 / 156800907780618310$

[71] E. F. Lewison, J. L. Grow and F. H. Trimble, "The Hormone Treatment of Advanced Breast Cancer: Comparative Therapy with Testosterone and Two Experimental Androgens," American Surgeon, Vol. 26, 1960, pp. 278283.

[72] E. Neninger, B. G. Verdecia, T. Crombet, C. Viada, S. Pereda, I. Leonard, et al., "Combining an EGF-Based Cancer Vaccine with Chemotherapy in Advanced Nonsmall Cell Lung Cancer," Journal of Immunotherapy, Vol. 32, No. 1, 2009, pp. 92-99. doi:10.1097/CJI.0b013e31818fe167

[73] B. Garcia, E. Neninger, A. de la Torre, I. Leonard, R. Martinez, C. Viada, et al., "Effective Inhibition of the Epidermal Growth Factor/Epidermal Growth Factor Receptor Binding by Anti-Epidermal Growth Factor Antibodies Is Related to Better Survival in Advanced NonSmall-Cell Lung Cancer Patients Treated with the Epidermal Growth Factor Cancer Vaccine," Clinical Cancer Research, Vol. 14, No. 3, 2008, pp. 840-846. doi:10.1158/1078-0432.CCR-07-1050

[74] C. L. Mackall, F. T. Hakim and R. E. Gress, "Restoration of T-Cell Homeostasis after T-Cell Depletion," Seminars in Immunology, Vol. 9, No. 6, 1997, pp. 339-346. doi:10.1006/smim.1997.0091

[75] C. L. Mackall, T. A. Fleisher, M. R. Brown, I. T. Magrath, A. T. Shad, M. E. Horowitz, et al., "Lymphocyte Depletion during Treatment with Intensive Chemotherapy for Cancer," Blood, Vol. 84, No. 7, 1994, pp. 2221-2228.

[76] C. L. Mackall, T. A. Fleisher, M. R. Brown, M. P. Andrich, C. C. Chen, I. M. Feuerstein, et al., "Age, Thymopoiesis, and CD4+ T-Lymphocyte Regeneration after Intensive Chemotherapy," The New England Journal of Medicine, Vol. 332, No. 3, 1995, pp. 143-149. doi:10.1056/NEJM199501193320303

[77] F. T. Hakim, R. Cepeda, S. Kaimei, C. L. Mackall, N. McAtee, J. Zujewski, et al., "Constraints on CD4 Recovery Postchemotherapy in Adults: Thymic Insufficiency and Apoptotic Decline of Expanded Peripheral CD4 Cells," Blood, Vol. 90, No. 9, 1997, pp. 3789-3798.

[78] C. L. Mackall, F. T. Hakim and R. E. Gress, "T-Cell Regeneration: All Repertoires Are Not Created Equal," Trends in Immunology, Vol. 18, No. 5, 1997, pp. 245-251. doi:10.1016/S0167-5699(97)81664-7

[79] C. L. Mackall, C. V. Bare, L. A. Granger, S. O. Sharrow, J. A. Titus and R. E. Gress, "Thymic-Independent T Cell Regeneration Occurs via Antigen-Driven Expansion of Peripheral T Cells Resulting in a Repertoire that Is Limited in Diversity and Prone to Skewing," The Journal of Immunology, Vol. 156, No. 12, 1996, pp. 4609-4616.

[80] G. Gonzalez, T. Crombet, F. Torres, M. Catala, L. Alfonso, M. Osorio, et al., "Epidermal Growth FactorBased Cancer Vaccine for Non-Small-Cell Lung Cancer Therapy," Annals of Oncology, Vol. 14, No. 3, 2003, pp. 461-466. doi:10.1093/annonc/mdg102 
[81] G. Gonzalez, T. Crombet, E. Neninger, C. Viada and A. Lage, "Therapeutic Vaccination with Epidermal Growth Factor (EGF) in Advanced Lung Cancer: Analysis of Pooled Data from Three Clinical Trials," Human Vaccines, Vol. 3, No. 1, 2007, pp. 8-13. doi:10.4161/hv.3.1.3537

[82] G. Gonzalez, T. Crombet, M. Catala, V. Mirabal, J. C. Hernandez, Y. Gonzalez, et al., "A Novel Cancer Vaccine Composed of Human-Recombinant Epidermal Growth Factor Linked to a Carrier Protein: Report of a Pilot Clinical Trial," Annals of Oncology, Vol. 9, No. 4, 1998,

\section{Abbreviations}

EGF: epidermal growth factor

EGFR: EGF receptor

NSCLC: non-small cell lung cancer

OS: overall survival

PD: progressive disease pp. 431-435. doi:10.1023/A:1008261031034

[83] T. Crombet, E. Neninger, J. Gonzalez, P. C. Rodriguez, B. Garcia, X. Popa, et al., "EGF-Based Cancer Vaccine: Optimizing Predictive and Surrogate Biomarkers," ASCO Annual Meeting, Chicago, 2013.

[84] C. Gridelli, P. Maione, A. Rossi, G. Palazzolo, G. Colantuoni and E. Rossi, "Management of Unfit Older Patients with Advanced NSCLC," Cancer Treatment Reviews, Vol. 35, No. 6, 2009, pp. 517-521. doi:10.1016/j.ctrv.2009.04.011

PFS: progression free survival

PR: partial response

PS: performance status

SD: stable disease

TKI: tyrosine kinase inhibitor

VEGF: vascular endothelial growth factor 